[Vicino Oriente XXII (2018), pp. 49-90]

\title{
POMEGRANATE (PUNICA GRANATUM L.) FROM MOTYA AND ITS DEEPEST ORIENTAL ROOTS
}

\author{
Lorenzo Nigro - Federica Spagnoli \\ Sapienza University of Rome
}

The pomegranate bush raises its voice - tiny, insistent, and shrill: My seeds shine like the teeth of my mistress, the shape of my fruit is round like her breasts. I'm her favorite, I know, sweetest tree in the orchard, looking my best through every season. ${ }^{1}$

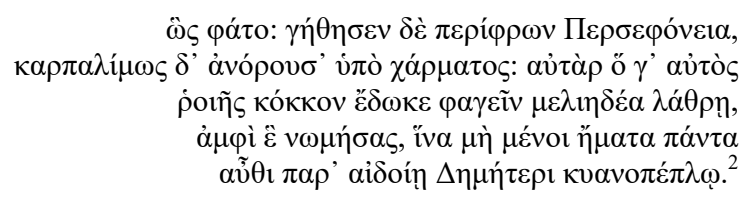

Pomegranate remains and representations found in the Phoenician site of Motya in Western Sicily give the cue for a summary study of this plant and its fortune in the Near East and the Mediterranean. Fruits offered in wells, a terracotta relief depicting a pomegranate held by a goddess found in the Sacred Area of the Kothon at Motya, and, especially, a pottery vase in the shape of a pomegranate retrieved inside the Temple of Astarte in the same compound, witness the symbolic transcultural role of this fruit and of the pomegranate tree in ancient Mediterranean, from its farthest oriental origins to modern art and religion.

Keywords: pomegranate; Punica granatum L.; Motya; Astarte; Demetra

\section{PomegranAte: THE Divine POME [LN]}

Pomegranate is a divine gift in the imagery of antiquity. It has so many evocative features: its blossom and flower, the squatted fat spherical shape of the pome, with a pointed or crowned tip (fig. 1), emblem of power; its shining red colour resembling even gold which stain at the touch; the innumerable - 613 - ruby-red seeds (actually, the fruit is made only of seeds) hinting at fecundity; its curative blood-red juice; its yellow lenitive inner rind; its oriental origins. It was depicted and reproduced in ancient art as a major symbol of fertility, abundance, perfection and sanctity.

It was because of the green splendour of the shrub, the rainbow pink and red of its flower, the purpling, crimson and shining red of the fruit, the regularly fitting geometry of the seeds. The pomegranate ripens at the end of summer, quenching with its juice the latest days of hot.

\footnotetext{
Papyrus of Turin $12^{\text {th }}$ century BC, translation in J.L. Foster (1992, 83-84).

"When he said this, wise Persephone was filled with joy and hastily sprang up for gladness. But he on his part secretly gave her sweet pomegranate seed to eat, taking care for himself that she might not remain continually with grave, dark-robed Demeter": F. Cassola ed. 1986, "Inno a Demetra", Inni Omerici, vv. 370-374.
} 
The ancient Semitic name of this fruit is "rummanu", is both in Assyrian and Aramaic, "inhmn" or " "nhman" in Egyptian, "haraman" in Coptic, רُمَّان "rimmon" in Hebrew and "roummana" in Arabic. Several toponyms in ancient Near Eastern sources mention the pomegranate referring to places where the tree was cultivated. ${ }^{3}$

Later on, Greek and Latin sources more generically designated the fruit as $\mu \tilde{\eta} \lambda o v / m a l u m$ or $\rho$ ó $\alpha /$ pomum granatum (i.e. full of seeds), that is the antesignanus of fruits. ${ }^{4}$

Pomegranate was cultivated in Motya at least since the beginning of the Phoenician colony, in the $8^{\text {th }}$ century $\mathrm{BC}$, as pollen and seeds found in the excavations testify to. It was among the offering to the goddess Astarte, and depicted on a terracotta possibly portraying Demeter both found in the Sacred Area of the Kothon ( $\S 6$.$) . Pomegranate trees are still$ present on the island..$^{5}$ All these Motyan pomegranates, images, fragments and relics of ancient fruits, as well as current fruits, have been analysed to offer an overall picture of pomegranate at Motya, characterizing the fruit, and studying its uses as documented by archaeology.

3 A famous reference is in Zechariah 12:11 which mentions the site of Hadad Rimmon, just $1 \mathrm{Km}$ NW of Taannek, where King Josiah died (2 Kings 23:29-30) in the battle against Pharaoh Necho (Menkheperra Nekau I, 672-664 BC). The site is identified with the modern Palestinian village of Rummanah.

4 In Greek mythology the Hesperides guarded the garden where the golden pomes grew up: these could have actually been pomegranates (see below $\S 4.1$.).

5 Chemical pharmaceutical characterization of present-day Punica granatum L. samples from Motya examined by Prof. Rino Ragno is Sapienza, who we deeply thank, is illustrated below. Materials: 96\% Ethanol, formic acid and bi-distilled water were purchased from Carlo Erba (Milan, Italy), glacial acetic acid and ethyl acetate were purchased from Fluka (Milan, Italy), acetonitrile RS for HPLC was purchased from Sigma-Aldrich Chemistry (Milan, Italy). Punicalagin $(\geq 98 \%)$ and ellagic acid $(\geq 95 \%)$ were purchased from Sigma-Aldrich Chemistry. All the other reagents were analytical grade reagents from Sigma-Aldrich Chemistry. Samples preparation: pomegranate fruits were used as whole fruit or separated in two parts: arils and peels (exocarp and mesocarp). Whole fruits or only peels, manually separated, were washed, blended in a mixer at 16000 $\mathrm{rpm}$ for $30 \mathrm{sec}$ and extracted as described. Extraction methods - whole fruit or peels extraction with ethanol and acidified water: $10 \mathrm{~g}$ of the blended whole fruit or the manually separated peels were extracted with 40 $\mathrm{mL}$ ethanol: acidified water (5\% acetic acid) in 3:1 ratio. Samples were stirred for $24 \mathrm{~h}$ at room temperature in the dark. The extraction mixture was well decanted and filtered on paper, then evaporated at $40{ }^{\circ} \mathrm{C}$ in the dark obtaining a purple-red sticky residue (about $1.9 \mathrm{~g}$ ) that was stored at $-20^{\circ} \mathrm{C}$ or immediately analyzed. HPLC analyses: the residues from the hydro-alcoholic extracts obtained from the previous described procedures, were weighed, dissolved in water and filtered before injection. HPLC analyses of anthocyanins ellagitannins were performed with a Perkin Elmer apparatus consisting of a Serie 200 LC pump, a Serie 200 DAD and a Serie 200 autosampler, including a Totalchrom Perkin Elmer software for the data acquisition. Chromatography was performed on a Luna (Phenomenex $\left.{ }^{\circledR}\right)$ RP18 column $(250 \times 4.6 \mathrm{~mm}$ i.d., $5 \mu \mathrm{m})$ using a mobile phase composed of acetonitrile (solvent A) and water containing $5 \%$ formic acid (solvent B), which in 20 min changed from $0 \% \mathrm{~A}$ and $100 \% \mathrm{~B}$ to $15 \% \mathrm{~A}$ and $85 \% \mathrm{~B}$ and then in other 20 min changed to $45 \% \mathrm{~A}$ and $55 \% \mathrm{~B}$, with a flow rate of $1 \mathrm{~mL} / \mathrm{min}$, at $\lambda 530 \mathrm{~nm}$ and at $\lambda 360 \mathrm{~nm}$. Punicalagin anomers $\alpha$ and $\beta$ and ellagic acid were identified in the samples by comparison of the retention times and UV spectra of pure external standards. The quantitative analyses were performed by calibration curves ranging from $1-100 \mathrm{mg} / \mathrm{g}$ $\left(\mathrm{y}=15.3 \mathrm{x}+26.8\right.$, with correlation coefficient $\left.\mathrm{R}^{2}=0.9986\right)$ for punicalagins and from $0.2-80 \mathrm{mg} / \mathrm{g}$ $\left(y=39.6 x+49.5\right.$, with correlation coefficient $\left.\mathrm{R}^{2}=0.9919\right)$ for ellagic acid, separately. 


\section{Pomegranate in THE ANCIENT NEAR EAST AND THE LEVANT [LN]}

The presence of pomegranate in the Levant, both the original fruit, Punica protopunica L., and the developed one, Punica granatum L., ${ }^{6}$ is archaeologically attested from the $4^{\text {th }}$ millennium BC. The spread of this plant from the Middle to the Near East occurred between the second half of the $4^{\text {th }}$ and the first half of the $3^{\text {rd }}$ millennium $\mathrm{BC}$, though some specimen reached the Fertile Crescent even before. ${ }^{7}$ This may be connected with Sumerian contacts and exchanges with the civilizations of ancient Iran, Afghanistan, Pakistan and India (Harappa and Mohenjo-daro in the Indus Valley). Long-distance trade towards India was practiced by Sumero-Akkadian city-states of Mesopotamia and Elam ${ }^{8}$ and this route is possibly the one through which the original pomegranate shrub (Punica protopunica L.) reached Mesopotamia, Anatolia, Syria and Palestine. The bigger and more developed species of Punica granatum L., instead, possibly developed in the Near East, as an effect of self-grafting or inosculation. Sumerians were possibly the protagonist of such development, as it is suggested by a stamp seal (fig. 2:a) of the Late Uruk period with a schematic pomegranate fruit and, especially, by the representation of regular (grafted in?) three branches pomegranate trees in the lower register of the carved alabaster vase from Uruk (fig. 2:b-c). The brilliant red and the yellow of its skin, the blood-red juice and the abundance of its stuffed up seeds, make the pomegranate suitable for symbolic associations with human fertility, and thus life and death. For this reason, in ancient Mesopotamian art it is often represented with the deities of fertility, fecundity, and abundance. In the Assyrian imagery pomegranate usually appears as Tree of Life (fig. 2:d-e). ${ }^{9}$

\footnotetext{
Taxonomy of Punica granatum L.: Punica granatum L. known as pomegranate, is a fruit-bearing deciduous shrub or small tree growing between 5 to 8 meters tall. It is planted either for its edible fruit or as an ornamental tree. Taxonomy: the pomegranate belongs to the family Lythraceae with only two different species namely Punica granatum and Punica protopunica. Punica grantum is the predominant species and cultivated worldwide whereas Punica protopunica is only restricted to the Island of Socotra (Republic of Yemen). Distribution and origin: Punica granatum have been cultivated in Iran, Iraq, Azerbaijan, Armenia, Afghanistan, Pakistan, India, Russia, Bangladesh and the Mediterranean region for several millennia. The origin of genus Punica is mainly native to Persia (modern day Iran). Name: the genus name Punica refers to the Phoenicians, who were active in broadening its cultivation, partly for religious reasons. The most plausible explanation for the name pomegranate is its derivation from the Latin word pomum meaning apple and granatus, which means seeded. The present vernacular name pomegranate is derived from the name Pomum (apple) granatus (grainy), or seeded apple. Utilization: owing to its medicinal and culinary utility, it has been mentioned in many ancient scriptures notably in Babylonian texts, the Book of Exodus, the Homeric Hymns and the Quran. Different part of the plant like, bark, leaves, fruit, fruit extract or juice and fruit rind have been reported to show various medicinal activities. Archaeobotany: the spread of pomegranate can be estimated by archaeological evidence, as described by Zohary and Spiegel-Roy (1975). Carbonized pips and fragments of pomegranate peels have been found from the Early Bronze Age in Jericho and Arad and remains of Punica species have been found in Nimrud/Iraq, in Sidon/Lebanon (Orendi - Deckers 2018), in Thera/Greece (Mavromati 2017) and Huelva/Spain (Pérez-Jordà et al. 2017). By the middle ages, pomegranate grew throughout the Levant and appeared in Egypt during the Middle Kingdom. Many wild groves can still be found thriving in the bottom of gorges throughout the Mediterranean and Central Asian region (IPGRI 2001).

Fateh et al. 2013, 23; Kokaj - Çakalli - Ismaili 2017, 133.

8 A clay token (or finial) found in a $4^{\text {th }}$ millennium BC stratum at Susa is shaped as a pomegranate (Punica protopunica L.) (Schmandt-Besserat 1992, fig. 18.2).

9 Moortgat-Correns 1989, 185; Muthmann 1982, 13, figs. 4-5; Lurker ed. 1971, 147, 161; Barnett 1982 , pl. $35: b$.
} 
In Syria-Palestine, pomegranate seeds were found in Ebla, ${ }^{10}$ Tell es-Sultan/Jericho, ${ }^{11}$

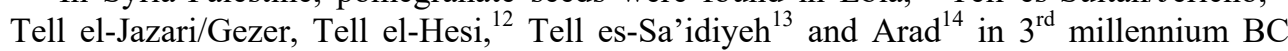
contexts, showing a capillary distribution at the time of the early urbanization. The spread of this species in the Levant increased in $2^{\text {nd }}$ millennium BC, and it was found in almost all excavated sites where paleo-botanic samples were collected and studied. At Ebla, it has been surmised that pomegranate trees were planted in the inner courtyard of Monument P3, a monumental cultic terrace in the Sacred Area of Ishtar. ${ }^{15}$ They were also retrieve in Tell ed-Dab'a, where seeds were found in the forecourt of Temple III, a temple of SyroPalestinian type (fig. 3:a). ${ }^{16}$ It is also possible that pomegranate trees were among the cultivated plants in the gardens of the Palace of the $13^{\text {th }}$ Dynasty $(1783-1640 \mathrm{BC})$. Tomb B35 at Jericho dating from Middle Bronze IIB (1700-1650 BC), roughly the same period of Tell ed-Dab'a's attestations, yielded an desiccated fruit (fig. $3: \mathrm{b}):{ }^{17}$ in the same tomb, along with wooden tables and bowls, ${ }^{18}$ a wooden box carved in the shape of a pomegranate divided into two halves was found (fig. 3:c). ${ }^{19}$

In Late Bronze Age Megiddo two golden pendants in shape of small pomegranates, possibly belonged to earrings, were found in the so-called "Treasure 3073" in stratum VIIA (LB IIB, 1300-1200 BC) Palace 2041 (fig. 3:d-e). ${ }^{20}$

Attestations in Egypt starts from the $2^{\text {nd }}$ millennium $\mathrm{BC}$ - if one excludes a small jar made of breccia stone dating from the Early-Dynastic period (3150-2686 BC) (fig. 4:a $)^{21}-$, when renewed relationships with the Levant during the $13^{\text {th }}$ Dynasty favoured the diffusion of the tree. A possible identification of the name " $\mathrm{hmn}$ " can be read on the silver chiselled handle of a dagger from Saqqara. ${ }^{22}$ Attestations become significantly more numerous from the $18^{\text {th }}$ Dynasty, thus suggesting that this fruit was imported from Palestine, which New Kingdom Pharaohs subjugated. Pomegranate, by instance, was found in the tomb of Djehuty, the Overseer of the Treasury during the reign of Hatshepsut at Thebes (TT110), ${ }^{23}$ and appears in the "Syrian Garden" of Thutmose III at Karnak (fig. 4:e). Always at Karnak, pomegranates appear in the representation of the feast of Opet. It was also found and in the aristocrats' residencies of Tell el Amarna. ${ }^{24}$ Furthermore, from Egyptian sources and

Wachter-Sarkady 1995, 242

Seeds fragments from Area B (Italian-Palestinian Excavations season 1998).

Lipschitz 1989, 272

Cartwright 1997.

Hopf 1978, 74

Matthiae 1993; 2002

Bietak 2009, 209-210, figs. 4-5.

Kenyon 1960, 392-393, pl. XVII:4; Hopf 1969, 357.

Kenyon 1960, pl. XVI.

Kenyon 1960, pl. XVII:1.

Loud 1948, pl. 215:113. About “Treasure 3073”: Nigro 1994, 154-155, fn. 58.

21 The small vase is the Liverpool World Museum (inv. 56.22.665); it was found in a tomb in Abydos. It has been suggested a dating in the New Kingdom, basing upon the absence of attestations of pomegranate before the Second Intermediate Period.

22 Loret 1892, 76-78; with an interesting reference to the military term "grenadier" from the type of bomb which contains, as like as the pomegranate fruit, a number of shells inside.

23 Hepper 1990, 62, 64.

24 Murray 2000, 625. 
ethnographic studies we know that ancient Egyptians made a wine from the pomegranate ${ }^{25}$ the rind was prepared against intestinal diseases and used for dyeing leather. The flowers were crushed to make a red dye, which could be also obtained by swiping the peel.

Stone (steatite) and ivory models of pomegranate, golden pendants in shape of pomegranate and a silver pomegranate vessel were found in the funerary goods of the Tomb Tutankhamon (fig. 4:b-d).

The presence of pomegranate plants along the coast of the Levant at Ugarit, Byblos, Sidon, Tell el-Burak and Tyre, is attested from the $18^{\text {th }}$ century $\mathrm{BC},{ }^{26}$ but possibly started in the first centuries of the $2^{\text {nd }}$ millennium BC. As symbol of life and fertility, pomegranate garlands appear on the golden hemispherical bowl found in the Temple of Baal at Ugarit (fig. 5:a), and in a bronze stand for incense-burner (fig. 5:b). ${ }^{27}$

In the same region, pomegranate was associated to Ishtar/Astarte as regards her chthonian aspects of goddess of wild nature and fertility, ${ }^{28}$

The recovery of numerous pomegranate seeds, skin fragments and flower parts from the late $14^{\text {th }}$ century BC Uluburun shipwreck ${ }^{29}$ provides a further indication of the preciousness of this fruit in antiquity. The presence of the pomegranate within the rich cargo of the Syrian merchant ship sunk near the southern coast of Anatolia confirms that it was deemed a luxury item destined to the urban élites. The spread of the pomegranate plant and its religious symbology and utilization in $14^{\text {th }}$ century BC Cyprus and Aegean are thus probably due to Canaanite and Syrian trade. Around the $10^{\text {th }}$ century BC, Phoenician colonists carried it (and its symbology and religious implications) to West Mediterranean, probably also thanks to the cultural mediation of the Ionian and eastern Aegean islands, such as Rhodes and Samos, ${ }^{30}$ which have very active trade navies on the western searoutes. $^{31}$

At Cyprus pomegranate is attested to from the $2^{\text {nd }}$ millennium $\mathrm{BC}$ onwards. It was again connected with Astarte as symbol of fertility also in her maritime dominion (pomegranate seeds may recall fish eggs). By instance, one may quote golden pomegranates decorated pendants and necklaces found in tombs at Enkomi and Ayos Iakovos (fig. 6:a-b) ${ }^{32}$

From the Iron Age pomegranate is widely spread over especially in funerary contexts of the Levant, reproduced in tombs, decorations, personal ornaments, urns and sarcophagi. This popularity is transversal to cultures and funerary customs, and affects all ethnic groups living in the Levant.

During the Iron Age I, pomegranates are typically applied to kernoi found in religious contexts. The best documented examples are known from $\mathrm{Gezer}^{33}$ and Megiddo ${ }^{34}$ (fig. 6:g).

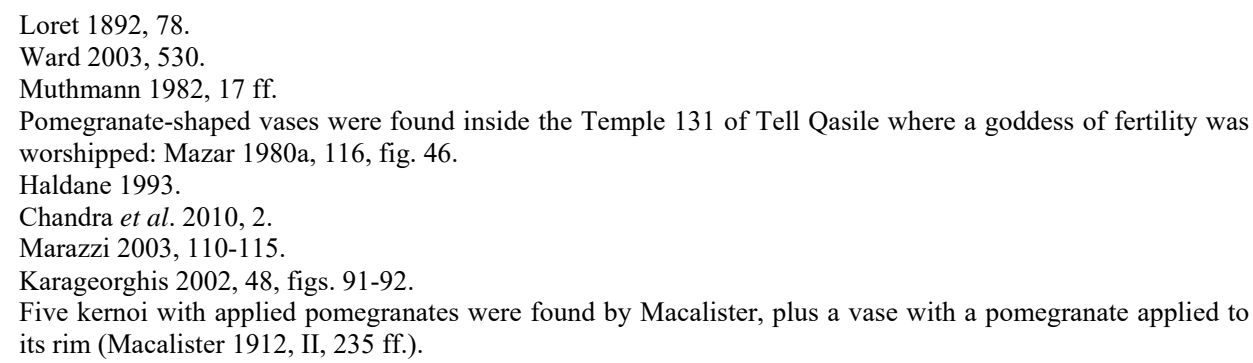


The role of pomegranates seems connected to pour liquids, as their replicas are pierced and communicate with the ring. ${ }^{35}$ Kernoi might have been used to offer up the pomegranate juice, as it is also documented by a small spouted jar which imitates the pomegranate crown nowadays in the Hecht Museum in Haifa. An ivory finial of sceptre carved as a slender pomegranate was found in Megiddo stratum IV (Iron IIB, 925-732 BC) (fig. 6:c). ${ }^{36}$

A special mention deserves Philistine Temple 131 of Tell Qasile where two pomegranate shaped vessels with red-slipped surface and black painted bands (fig. 6:e-f) were found together with a kernos also including these fruits, and several figurines and other zoomorphic vases. ${ }^{37}$ A libation vessels with a bunch of pomegranates applied ${ }^{38}$ may recall the representations of such bunches in Thutmose III "Syrian Garden" at Karnak.

Pomegranate combusted rinds and seeds were found in Tell es-Safi/Gath in Iron Age I cultic contexts. $^{39}$

In the Near East and the Levant pomegranate achieves a further symbolic value connected to the kingship ${ }^{40}$ and continue to be reproduced on textiles, wood, ivory, precious metals, as symbolic ornaments. Already in the $2^{\text {nd }}$ millennium BC, two small sceptres were found in Tell en-Nami bearing a finial in the shape of a pomegranate (fig. 7:a). ${ }^{41}$ In the $1^{\text {st }}$ millennium BC similar pomegranate finials were set on the top of bronze or ivory rods and sceptres found in Levantine temples, ${ }^{42}$ and represented on Neo-Hittite reliefs and stelas (in the hands of the Goddess Kubaba at Karkemish; fig. 6:h). ${ }^{43}$, on Neo-Assyrian reliefs ${ }^{44}$ and on Phoenician ivories. ${ }^{45}$ A paramount example of how pomegranate could be employed in personal ornaments and robes' decoration is offered by the Queens' tombs discovered underneath the North-West Palace of Ashurnasirpal II at Nimrud. Some outstanding pieces of jewellery, including diadems, pendants, earrings, beads, but also

34 One of the kernoi found in Megiddo stratum VI $\left(12^{\text {th }}-11^{\text {th }}\right.$ century BC) shows eight attachments: a cup where two turtle doves are drinking, two pomegranates, two jars and the head of a bull with pierced mouth from where the liquid contained in the ring-vessel could be offered up as a libation. The association of the doves with the pomegranates (apparently Punica protopunica L.) here recalls Ishtar/Astarte.

35 Bignasca 2000, 23-25 with previous bibliography.

36 Lamon - Shipton 1939, pl. 100:10.

37 Mazar 1980a, 116-117, fig. 46, pls. 37-38. In temple area a goblet (fig. 6:d) recalling the pomegranate-shaped vessels was found (Mazar 1980b, 51, fig. 40.13)

38 Mazar 1980a, 104-105, fig. 37.

39 Frumin - Weiss 2018, 79, fig. 6.

40 Abram 2009, 30.

41 Two bronze sceptres are on exhibit in the Israel Museum: inv. ns. IAA 1989-649, 1989-650 (picture from the website). A bronze thymiaterion from the same site shows decorative pomegranate pendants (fig. 7:c).

42 Artzy 1991, 49; 1995, fig. 2.14; Lachish, "Fosse-Temple" (Tufnell 1958, 87, pls. 28.7, 54.2). A small ivory pomegranate from the illegal market of antiquities, probably dating to the $8^{\text {th }}$ century $\mathrm{BC}$, now at the Israel Museum, Jerusalem (Avigad 1994; Abram 2009, 25-28), represents a still-maturing pomegranate fruit with the elongated calyx occupying half its height (fig. 7:b). As is the case for earlier Late Bronze Age pomegranate finials, its base is slightly hollowed, and probably originally fitted onto a rod (see also a specimen in the Israel Museum with a dove on the top, fig. 7:d). For the Paleo-Hebrew inscription incised on top, see Lemaire 1981 and 1984.

43 Marchetti - Peker 2018, with references to other Neo-Hittite monuments and iconography.

44 Börker-Klähn 1957-1971, 620, n. b9

45 Mallowan 1966, 506, 562, figs. 411, 505. Glass models of pomegranate of Phoenician production were currently given as funerary offerings in Iron Age Levantine and Egyptian tombs (fig. 7:e-f). 
engraved representations on ivory boxes, are decorated with pomegranates as symbols for fertility (fig. 8). ${ }^{46}$

Pomegranate became common decorative element in Assyrian and Achaemenid period in furniture, clothes, and architecture, as finial or appendix. Epitomic representations are those on the wall reliefs of the North Palace at Niniveh with king Ashurbanipal under an umbrella with pomegranate like finials and locks, also visible at Persepolis shading King Xerxes (fig. 7:g-h).

\section{Pomegranate in the Bible [LN]}

The Bible provides several interesting references to pomegranate (Hebr. rimmon). ${ }^{47}$ The earliest one is in the Book of Exodus (28:33-34 and 39:24-26) and refers to the fabrication with blue, purple and scarlet yarns of pomegranates tuft to embellish the hem of a ministerial robe. Textile "pomegranates" bordering priests' robes were alternated to golden bells. Similar tufts characterize Near Eastern élite's robes since the $2^{\text {nd }}$ millennium $B C$, as shown by Old-Syrian and Old-Babylonian royal statuary. The same kind of dresses decoration might be detected in modern fringes, like those of Arabs' keffiyeh.

Pomegranate are listed among fruitful plants (wheat, grape, fig) embellishing the Promised Land in the Book of Deuteronomy $(8: 8-7) .^{48}$

Garlands of two hundred bronze pomegranates ${ }^{49}$ encircled the capitals on top of the pillars flanking the entrance of Salomon's Temple in Jerusalem built by Phoenician architects and artisans (1 King 7:18-20, 42; 2 Kings 25:17; 2 Chron. 3:16, 4:13). Pomegranate is mentioned several times in the Song of the Songs as its halves are compared to lady's temples behind her veil $(4: 13,13,6: 7)$, and for it is a tree of a sacred garden $(6: 11,7: 2)$. If the pomegranate tree is dried up, this is a symbol of curse (Joel 1:12), on the contrary, its seeds are a figure of blessing (Haggai 2:19). Finally, according to Biblical tradition, pomegranate regularly bears 613 seeds, which coincides with the number of prescriptions (good deeds, mitzvot, in the Bible) in the Torah.

There exist a hypothesis concerning the identification of the "fruit of tree that is in the middle of the Garden" (the "forbidden fruit" from the tree of the knowledge of good and

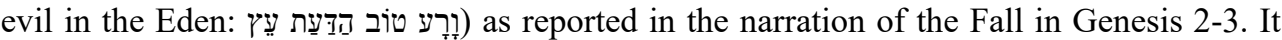
might be identified with a pomegranate, in the light of the high symbolic value of it in relation with the power over life and death that it symbolizes in the Bible and Quran. For this reason, the pomegranate was also considered a Tree of Life of the terrestrial paradise.

Finally, several Biblical toponyms are derived from the name of the pomegranate: Rimmon-parez (Numbers 33, 19), 'Ain-Rimmon = spring of the pomegranate (Joshua, 15:32 and 19:7; Nehemiah, 11:29; and Zechariah, 14:10), Gath-Rimmon = Pomegranate

Hussein 2016

Goor 1967 .

48 The whole quotation according to the Bible NIV: $«{ }^{6}$ Observe the commands of the Lord your God, walking in obedience to him and revering him. ${ }^{7}$ For the Lord your God is bringing you into a good land - a land with brooks, streams, and deep springs gushing out into the valleys and hills; ${ }^{8}$ a land with wheat and barley, grapes and fig trees, pomegranates, olive oil and honey; ${ }^{9}$ a land where bread will not be scarce and you will lack nothing; a land where the rocks are iron and you can dig copper out of the hills».

49 Ninety-six and one hundred according to Jeremiah 52:22-23. 
Press (Joshua, 21:24), Sela Rimmon rock of pomegranate (Judges, 20:45), and Beit Rimmon $=$ house of pomegranate $(2$ Kings, $5: 18){ }^{50}$

\section{Pomegranate in GREeCE [FS]}

During the $2^{\text {nd }}$ millennium $\mathrm{BC}$, the pomegranate is appreciated as an exotic fruit, rare and refined, by the urban aristocracies of the Near East, and it was exchanged as a luxury item and, contemporary, it bears a strong symbolic value both in sacred and funeral spheres.

The same symbolism is transmitted to the Greek culture at the beginning of the $1^{\text {st }}$ millennium BC. Even though the pomegranate tree was already cultivated in Greece, in local literary tradition the pomegranate continues to be considered as an allogeneic fruit coming from far territories and mythical places (an exotic fruit of "Paradise"). As an example, in the luxuriant garden of the palace of Alcinous King of Phaeacians, pomegranate is one of the fruit trees - pears, apples, figs and olives - that bears fruits all year round. ${ }^{51}$

One of the oldest representations of pomegranate in the Greek world, is on a pair of gold earrings found in the burial of the "Rich Lady of Areiopagus", 52 (fig. 9:a) which included several objects imported from the Near East in its funerary furnishing, dating back to the mid- $9^{\text {th }}$ century BC. The choice of pomegranates, as well as the presence of an ivory pyxis decorated on the lid with the representation of five models of granary, may symbolically indicate the prosperity of the family of the Lady, supported by symbols of fertility and abundance. ${ }^{53}$ In the necropolis of Kamiros (Rhodes), the pomegranate is represented on several jewel plaquettes depicting the Potnia Theron, the Mother Goddess, Lady of the wild beasts (fig. 9:h), whose relationship with the oriental goddesses of fertility is also evidenced by the common iconographic set, including also the pomegranates.

The pomegranate as attribute of a deity of fertility, in association with other Levantine votives, is attested to in the Heraion of Samos (fig. 9:b-c). ${ }^{54}$

To the pomegranate is given a divine value as fruit of the Netherworld in the myth of Demeter and Persephone/Kore. ${ }^{55}$ In $7^{\text {th }}$ and $6^{\text {th }}$ century BC, it appears as a standard element of Greek aristocratic tombs, both as a piece of the grave goods (fig. 9:d-e) ${ }^{56}$ or depicted on funerary vases. ${ }^{57}$

50 The same kind of toponyms appear also in the Mishnah and in the Talmud: Geva Rimmon = Hill of Pomegranate; (Tosefta Suta, 11, 14); Beq'at Rimmon = Pomegranate Valley (Jerusalem Talmud, Hagiga, Chapter 3), and, variantly, Biq'at Beit Rimmon = Valley of the House of the Pomegranate (Midrash Bereshit Raba, 64, 10)

51 Od. VII, 115.

52 Coldstream 1995, 398, pl. 99:a-b.

53 The representation of five granaries probably indicates also that the family of the Lady was included among the pentacosiomedimnoi, the highest social class of Archaic Athens: Coldsteram 1995, 395, pl. 97:c.

54 Immerwahr 1989, 407. The clay pomegranates found at Samos have a small hole piercing the corolla to be hung up as votive offerings: Bignasca 2000, 141.

55 Od. XI: 589.

56 CVA The Hague 1, 4, pl. 2.9 (Attic, Geometric period); CVA Kassel 2, 18, pl. 54.3; CVA Berlin 4, 31, pl. 169.1 (Rhodes, mid- $6^{\text {th }}$ century BC).

57 CVA Leiden 2, 2-3, pl. 56. 4-7, 550 BC. In this Black-figured loutrophoros, ascribed to the Painter of London $\mathrm{B} 76$, the pomegranate is represented as a funerary offering. It is carried with other votives, as the lotus flower and the wreath, by "penguin" women in procession, dressed with fillets and necklaces. 
In $5^{\text {th }}$ century $\mathrm{BC}$ Greek painting, the pomegranate is often represented on funerary vessels in scenes where the fruit is offered to deceased, recalling such myth of Persephone. The pomegranate provides the nourishment for the journey of the dead across the Netherworld. Replicas of pomegranate in gold, silver, electrum, marble, breccia, ivory and pottery, including vases, found among the grave goods of aristocratic tombs are often representative of the high status of the deceased. ${ }^{58}$ The most popular iconographies related to pomegranates in Greece may be illustrated by the following examples: on an Attic White ground lekythos ${ }^{59}$ a young woman carries ribbons and pomegranates, contained in a large basket, and a lekythos as gifts to a warrior, perhaps the deceased standing near a (funerary?) stelae (fig. 9:f). ${ }^{60}$ On another Attic lekythos of the same type and chronology, a woman is offering a basket containing ribbons, crowns and vases for perfumed oils, to a man holding in his hands a pomegranate and a rod or scepter during a funerary ceremony. A similar offering scene with inverted roles (woman with rod/scepter, man with funerary offerings including the pomegranate) appears on an Attic Red-Figured lekythos dated between 475 and $425 \mathrm{BC}^{61}$

The myth of Hades and Persephone is a very popular subject in pottery, and it is largely appreciated even outside the Greek world: as an example, Hades and his bride Persephone with a pomegranate in her hands are represented at the center of an Attic Red-Figured kylix from Vulci (430 BC) in the British Museum. ${ }^{62}$

Also in choroplastic the representation of the pomegranate is linked to Demeter and Kore/Persephone ${ }^{63}$ Clay reproductions of pomegranates are attested as votive offerings in innumerable sanctuaries and tombs of Magna Graecia (fig. 10:a): $:{ }^{64}$ terracotta statuettes of animals, fruits and sometimes flowers often substituted the corresponding natural, more enduring and, especially in the case of animals, less expensive subjects. ${ }^{65}$ Terracotta pomegranates are among the votive offerings of the sanctuary of Rossano di Vaglio, Metaponto (loc. Crucinia), Castelluccio, and in the urban sanctuaries of Metaponto and Eraclea dedicated to Demeter (fig. 10:b) ${ }^{66}$ The pomegranate flower is represented on a frieze adorning a tomb of Metaponto dating to the second half of the $5^{\text {th }}$ century $\mathrm{BC}$, and in a tomb of the necropolis of S. Arcangelo - S. Brancato (T. 23). ${ }^{67}$ In the $4^{\text {th }}$ century BC the Punica granatum L. is represented on the wall-painted tombs of Paestum (fig. 10:c). ${ }^{68}$ The

58 Immerwahr 1989, 409

59 The specimen is dated to the first half of $5^{\text {th }}$ century BC, and it is kept today in the Antikensammlung Berlin Museen.

60 Riezler 1914, pl. 19; $A R V^{2}$, 749.6; CVA Berlin 12, 27-29, fig. 2, pls. 11-12.1 (4740, 4741).

${ }^{61} \quad A R V^{2}, 669.45 ;$ Para, 521; Burn - Glynn 1982, 136; Add $^{2}, 278$.

62 Algrain 2014, 155, fig. 96; Gais 1978, 365-366, figs. 15-17 (A, B, I); Arafat 1990, pl. 29 (A, B); Avramidou 2011, 8-9, 15, 112-113, figs. 2.4-2.6, 2.15, pl. 10A-C (A, B, I); $A R V^{2}, 1269.3$; Bemmann 1994, 308, fig.10 (I); Beazley 1925, 425.5; Boardman 1989, fig. 239 (I); Add. $^{2}, 356$.

63 See, as an example, the representation of two figures, probably Hades and Kore/Persephone on the funerary stelae from Chrysapha (Sparta) (fig. 9:g): Blümel 1964, no. 16 (550-540 BC).

64 Russo - Vicari Sottosanti 2009, 24, fig. 51

65 Barra Bagnasco 1996, 221.

66 De Faveri 2007, 162-163: "Le melagrane fittili sono documentate nel santuario di Demetra ad Eraclea (Gertl 2014, 231, fig. 4:1) e nel santuario di Metaponto (Meirano 1996, 70)".

67 Mandič - Vita 2014.

68 Pontrandolfo - Rouveret 1992, 35; Pontrandolfo 1996, 464-465. 
pomegranate is a favoured subject also in jewellery, as shown by several examples found in the rich tombs of Southern Italy in $6^{\text {th }}-4^{\text {th }}$ century BC (fig. 10:d). ${ }^{69}$

Votive statuettes of goddesses handing a pomegranate were found in several Sicilian Thesmophoria, ${ }^{70}$ the extra-moenia sanctuaries devoted to Demeter, allowed for married woman only, ${ }^{71}$ where the human and agricultural fertility was celebrated. ${ }^{72}$

Hera, Artemis and even Athena are sometimes represented with a pomegranate as an ornament. ${ }^{73}$ In the Greek culture, therefore, the pomegranate is the symbol of those deities that, although in different intents and prerogatives, were responsible for the nature and the natural and reproductive courses of humans, animals and plants. ${ }^{74}$

\subsection{Pomegranate in Greek mythology}

In Minoan and Mycenaean traditions, the pomegranate is linked to the cult of the Meteres, ancestral deities of the wild nature and fertility ${ }^{75}$. Such prerogatives are transmitted in Greek mythology to Demeter, ${ }^{76}$ the goddess of luxuriant nature, and to her daughter Persephone. The pomegranate fruit holds a central role in the mythological story of these goddesses. The myth tells that Hades, the ruler of the Underworld, fallen in love with the young lady, raped Persephone, taking her in the Netherworld. Demeter, thanks to the intercession of Zeus, got her daughter back. However, Hades gave to Persephone some pomegranate seeds to eat, and by this way, he kept his bride inextricably linked to him and to the Netherworld. ${ }^{77}$ Persephone, therefore, can stay the two thirds of the year with her mother on the earth, but she has to spend the rest of the year with her husband in the Netherworld. In this period, corresponding to the autumn/winter, the nature dies, and earth and animals do not reproduce. When in spring and summer time Persephone came back to the light, nature awakens, and the fruits grow up.

In this myth, the pomegranate plays a symbolic role of primary importance because it is the element that keeps the linkage with Hades and thus triggers the alternation of Persephone's presence on the earth and, indirectly, natural cycles and seasons. Significantly, the pomegranate tree blooms at the beginning of summer, and its fruits are ripe at the beginning of autumn: the ripening of the pomegranate matches with the return of Persephone to Hades, and consequently the lethargy of the nature during the winter months. The pomegranate represents the seasonal passage and is a symbol of the seasons of human life. At the same time, it also indicates the faculty to trigger this change and can be interpreted as a symbol of renewal and rebirth.

69 See as an example the rich grave good of T.102 of Braida del Vaglio, PZ ( $6^{\text {th }}$ century BC): Bottini 1996, 546. Other attestations in De Faveri 2007, 163.

Sfameni Gasparro 2008

De Miro 2008, 48-49, fig. 8:4.

Parisi 2017, 574-576; Lippolis - Parisi 2012.

Bignasca 2000, 139

Bonnet 1996, $94-96$ for epigraphic evidences.

Fox 1916, 229

${ }^{76}$ In ancient Greek religion, the figure of the Mother Goddess is probably the result of the syncretism between Minoic-Mycenaean Great Mother and Anatolic Cybele, occurred during the $7^{\text {th }}$ century BC (Burkert 2010, 345,129, n. 22: PY fr. 1202 ma-te-re te-i-ja). Given the difficulty to fit this deity through the genealogy of Greek pantheon, the Mother Goddess was later switched for Demeter and her mythology: Burkert 2010, 346.

77 Thompson 1955-1958, C. Tabu 225.1, eating and drinking tabu. 
Furthermore, in Mycenaean and Greek mythology the pomegranate is also linked to another major goddess that inherits the characteristics of the Mother Goddess. Hera, the wife of Zeus, received a tree of golden fruits from Gaia as wedding gift. The wonderful tree was planted in a Garden placed at the western borders of the Mediterranean, guarded by the nymphs Hesperides, a personification of western Ocean waves, the daughters of Night and Erebus. As a further safeguard of the Garden there was a never-sleeping, hundred-headed dragon named Ladon. The precious golden pomes $(\mu \tilde{\eta} \lambda \eta)$ had the power to give immortality when eaten and were also considered in related myths as symbols of power. These characteristics, and the identity of the goddess who received the golden pomes tree, bear the suggestive hypothesis that the golden fruits were actually pomegranates. ${ }^{78}$ The pomegranate is, in facts, one of the most common attributes of Hera in Western Mediterranean, and, especially in Southern Italy, where the goddess was widely worshipped. $^{79}$

In the Phoenician pantheon, Astarte is the goddess that better embodies the power of presiding over natural rhythms and the cycle of seasons, acquiring several aspects of similar goddesses, such as Egyptian Hathor, Greek Hera and, later on, Isis and Demeter. During the $5^{\text {th }}$ century BC, when the influence of the Hellenic culture over Phoenician-Punic world increased in Sicily, Astarte gathers the chthonic aspects of Demeter in cults, rituals, symbols, and iconographies epitomized by the pomegranate. ${ }^{80}$

\section{Pomegranate in Phoenician and Punic Mediterranean [FS]}

It is highly probable that the diffusion of pomegranate in western Mediterranean is due to Phoenician expansion as illustrated by a plea of archaeo-botanic finds and indirectly suggested by the Latin name of this fruit. Pomegranate first reached Sicily (Motya) and North Africa (Utica and Carthage) and then was Carthage itself to contribute to its capillary spread over the Baleares, the Iberian Peninsula and Sardinia, which eventually will transmit it to the Etruscan and Roman world (which fall beyond the scope of the present contribution).

\subsection{Carthage and the North Africa}

\section{[...] Sed circa Carthaginem punicum malum cognomine sibi vindicat;} aliqui granatum appellant. ${ }^{8}$

In this renowned pass of Naturalis Historiae, Plinius the Elder tells us about the provenance and diffusion of Punica granatum L. from North Africa to other Mediterranean regions, such as Rome. Archaeo-botanic studies demonstrated that pomegranate was a very popular fruit in Carthage between the $3^{\text {rd }}$ and the $2^{\text {nd }}$ century $\mathrm{BC}:{ }^{82}$ palaeo-botanic analysis

78 The renowned pinax from Locri Epizefiri (460 BC) represents one young lady, probably one of the Hesperides, picking pomegranates, in front of a seated woman, perhaps a bride (Hera): Orlandini 1983, n. 468. Maddoli 1996, 489-493.

80 Ribichini 2015.

81 Plin. Nat. Hist. 13.31: but the vicinity of Carthage is claimed more particularly as its own by the fruit the name of which is the "Punic apple"; though by some it is called "granatum".

82 Van Zeist - Bottema 1982; van Zeist - Bottema, - van der Veen 2001, 7-8; Lancel 1992, 192-195. The conservation of pomegranates destined to exportation is the topic of Mago's work. The Carthaginian author 
of seeds found in the area of the harbor of Carthage revealed that more than half of collected samples belonged to Punica granatum L., thus showing the vast distribution of such fruit, which reached a peak of popularity in North Africa under the Carthaginian rule.

The presence of pomegranate at Carthage is known earlier, however, as it goes back to the $7^{\text {th }}$ or even $8^{\text {th }}$ century $\mathrm{BC}$, when in archaic tombs terracotta replicas of pomegranate were found, like in Levant and in Greece. Nevertheless, pomegranate replicas in funerary set continue to be attested in following centuries $\left(6^{\text {th }}-3^{\text {rd }}\right.$ century BC $) .{ }^{83}$

Pomegranates representations are very common on Tophet stelas of the $4^{\text {th }}$ and $3^{\text {rd }}$ century $\mathrm{BC}$, again due to the symbology of this fruit in connection with death and rebirth. While in the archaic period pomegranate seems to be a prerogative of mercantile aristocracy, in the following periods it gains a great popularity in the carved imagery of subaltern classes.

The fortune of pomegranate as subject depicted on funerary stelas is probably also due to the introduction of the cult of Demeter and Kore at Carthage at the beginning of the $4^{\text {th }}$ century $\mathrm{BC},{ }^{84}$ as attested to by Diodorus, during the crisis following the defeated of Himilco in Sicily ${ }^{85}$.

From a mere religious point of view, the introduction at Carthage of the cults of such goddesses, like in Motya in the $5^{\text {th }}$ century BC, triggered syncretistic phenomena with the other Carthaginian female deities, Astarte and, especially, Tanit, who inherited Kore's iconography in their representations on local coins. ${ }^{86}$ Many attributes of Demeter and Kore in the Greek tradition, among which the pomegranate was one of the most relevant, merged into the iconography of Tanit, also thanks to the common connection of the funerary world

who lived in the $2^{\text {nd }}$ century $\mathrm{BC}$, was translated into Greek and Latin by Cassius Dionisius, and became a major source for Roman authors such as Plinius the Elder (Plin. Nat. Hist. 1.51; 8.84; 10.98). By illustrating Carthaginian agricultural skills, Mago describes the techniques for the preservation of pomegranates to be transported by the sea as reported by Latin sources. Mago explains that the best way to ship pomegranate and preserve their fragrance is to sunk them into sea water or in humid soil (Plin. Nat. Hist. 15.20). This may indicate the importance attributed to pomegranate production and trade in Carthage as one of the agricultural industry of Carthaginian aristocracy. This may well explain the great number of seeds of Punica granatum L. found in the harbour of Carthage, where these fruits underwent the preservation treatments described by Mago.

83 Campanella 2008, 63

84 Xella 1969.

85 Diod. XIV. 77: [4] The Carthaginians, against whom the gods were clearly fighting, at first gathered in small groups and in great confusion and besought the deity to put an end to its wrath; thereupon the entire city was seized by superstitious fear and dread, as every man anticipated in imagination the enslavement of the city. Consequently, they voted by every means to propitiate the gods who had been sinned against. [5] Since they had included neither Kore nor Demeter in their rites, they appointed their most renowned citizens to be priests of these goddesses, and consecrating statues of them with all solemnity, they conducted their rites, following the ritual used by the Greeks. They also chose out the most prominent Greeks who lived among them and assigned them to the service of the goddesses. After this they constructed ships and made careful provision of supplies for the war. [trans. C.H. Oldfather, Cambridge, Mass.: Harvard University Press 1989] Carthage's strategies as described by Diodorus possibly reflect some deep changes of Carthaginian politics and society, following the emergence of the agrarian oligarchy. Such socio-economic transformations affected also the religious sphere, as the introduction of the cult of Demeter and Kore among the official cults of the city testifies to. These new cults were put under the control of the most eminent Greek inhabitants of the city. They denote a renovated attention towards what was happening in Carthage's protectorate in Sicily, as also the following military activities will demonstrate: De Vincenzo 2012, 20

86 Acquaro 2008. 
of the two goddesses, Kore and Tanit. Such associations are made evident by the imagery of Punic and Neo-Punic stelas found in necropolises, tophets and temples of North Africa, where the pomegranate is a very common motive, either as main figurative element, ${ }^{87}$ and as attribute of Tanit, represented on the top with bunches of grapes and ears of wheat (fig. 11:a), ${ }^{88}$ or part of the decorative frames. ${ }^{89}$ In some cases, the pomegranate appears in the hands of the dead or the deity standing at the middle of the carved representation. ${ }^{90}$ Moreover, from stelas representations we may infer that pomegranate played also a role in architectural decorations: on a stelae from Carthage dating to the $2^{\text {nd }}$ century $\mathrm{BC}^{91}$ it appears over the capital of an Ionic column in what is interpreted as a temple (fig. 11:b). This suggests that in Carthage temples included such kind of columns and capitals bearing pomegranates exactly as it is known for Salomon's Temple in Jerusalem and for the Temple of Melqart in Tyre.

\subsection{Iberian Peninsula}

The presence of pomegranate in the Iberian Peninsula ${ }^{92}$ possibly antedates its actual archaeological identification from the $6^{\text {th }}$ century $\mathrm{BC}$ in the coastal region reached by Phoenicians, ${ }^{93}$ which probably were responsible for the introduction of such tree in Andalusia. From that time onwards, the cultivation of pomegranate extended to the whole peninsula not only on the coasts, but also in the hinterland. The earliest pomegranate was found in Huelva ${ }^{94}$ again demonstrating the stable connections established between the Tartessian culture and Phoenicians, who possibly were the source of the plant.

In the archaeological record, pomegranate is basically attested to in funerary contexts. The most ancient attestations are from the necropolis of La Fonteta (Valencia), where pomegranates are included into aristocratic tombs of the $6^{\text {th }}$ century BC. ${ }^{95}$ Pomegranateshaped pottery vessels are also known in the coeval necropolises of La Bobadilla (Jaén), ${ }^{96}$ and, successively, in the tombs of the first half of the $5^{\text {th }}$ century $\mathrm{BC}$ of the necropolis of Tútugi (Granada) (fig. 11:c), ${ }^{97}$ and of the $4^{\text {th }}$ century BC of Cerro del Santuario (Baza, Granada). ${ }^{98}$

Also in Iberia, pomegranate presence in archaeological contexts increases with the strengthening of Carthage control over the region, as it is suggested by the great quantities of seeds of this fruit retrieved in Andalusian harbours, ${ }^{99}$ which also shows the importance of pomegranate trade for local economy at that time. ${ }^{100}$

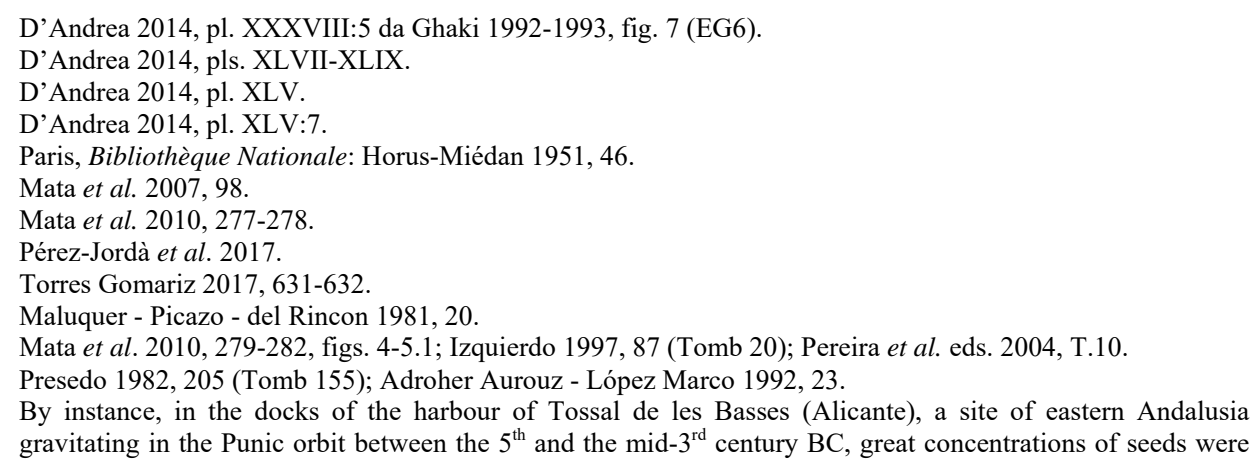


From the $5^{\text {th }}$ century $\mathrm{BC}$ pomegranate is attested to also in domestic contexts: in the residential quarter of Coimbra de Barranco Ancho (Jumilla), where a Punic amphora painted in red with a pomegranate garland was found (fig.11:d). ${ }^{101}$ The presence in tombs is exemplified by findings in Cadiz. ${ }^{102}$ Pomegranate attestations in domestic contexts progressively increase between the $3^{\text {rd }}$ and the $1^{\text {st }}$ century BC. In the meantime, such fruit continues to be present in funerary contexts. Its popularity is demonstrated by its presence in several different places of ordinary life: in Puntal dels Llops (Olocau, Valencia) burnt pomegranate residuals were found inside an amphora (fig. 11:e) ${ }^{103}$ representations of pomegranates, moreover, are numerous also on painted pottery (fig. 11:f-g). ${ }^{104}$

\subsection{Phoenician and Punic Sardinia}

The attestation of pomegranate in Phoenician and Punic Sardinia ${ }^{105}$ is mostly connected to the funerary realm. This fruit appears in funerary symbology as shown by a pomegranate-shaped vase found in a tomb of the Punic necropolis of Olbia. ${ }^{106}$ From Tharros, in the Collezione Chessa now in the National Museum at Sassari, are enlisted some golden pendants in the shape of pomegranates, ${ }^{107}$ a quite common feature also in the homeland, which can be dated from the $6^{\text {th }}$ or $5^{\text {th }}$ century BC (fig. 12:a). ${ }^{108}$

Pomegranate presences increase between the end of the $6^{\text {th }}$ and the $5^{\text {th }}$ century BC, as the influence of Greek culture affects figurative art, and, especially votive choroplastic. From this period and following in the Hellenistic period the iconography of the enthroned goddess with polos, identified with Demeter, becomes very popular, who usually holds in her hands a dove, a torch, a piglet and a pomegranate (fig. 12:b). ${ }^{109}$

A terracotta fruit, found in Tharros during the excavations of September 1962, might be regarded as a quince, often associated to the pomegranate ${ }^{110}$, which might be related to a

found, together with grapes and olives, thus indicating the agricultural vocation of such region for fruits and vegetables production and as junction of trade of agricultural products.

100 Torres Gomariz 2017, 635.

101 García Cano 1997; Badal García et al. 2010, 59, fig. 55.

102 As an example, on the noteworthy anthropoid sarcophagus found in the necropolis of Punta de la Vaca at Cadiz, the male figure holds a pomegranate in his left hand and a painted crown with flowers in his right hand. The carving of the stone points to the work of a Greek or very Hellenised Phoenician artist operating in the mid of the $5^{\text {th }}$ century BC (Almagro-Gorbea et al. 2010, 361, figs. 4-6).

103 Bonet - Mata 2002, 172-173, fig. 183.

104 See e.g. the painted repertoire of Edeta/Tossal de Sant Miquel (Valencia). In the residential quarter of the site numerous pomegranate seeds were found: Bonet 1995, 488; for pottery, fig. 206.

105 We wish to deeply thank professors Piero Bartoloni, Raimondo Zucca and Michele Guirguis of the University of Sassari for their enlightening suggestions about pomegranate in Sardinia.

106 Levi 1949, 28.

107 As a hypothesis, it is possible that also the typical Punic gold or silver heart-shaped medallion with granulated decoration is inspired by a stylized pomegranate. The more valuable items, among which is the renowned Medallion of Yada'milk, were found in archaic tombs of the $7^{\text {th }}$ and $6^{\text {th }}$ century BC at Carthage and Tharros: Ferron 1958-1959, 45-56; Ferron 1968; De Carthage à Kairouan, n. 109; Barnett - Mendleson 1987, 139-140, pl. 80 , no. $4 / 24 ; 148$, pl. 84 , no. $6 / 29 ; 166$, pl. 93 , no. $10 / 24$.

108 Crespi 1868, 24, nr. 31, pl. A, nr. 18; Moscati - Uberti 1987, 116, D63, D64, pl. XXXV.

109 Pesce 1961, 99, fig. 96; Uberti 1977, 30, 33-34, pl. XIII: 9.

110 Uberti 1975, 49, nr. A 163, pl. XXI. 
Punic sanctuary devoted to Demeter located by the Torre San Giovanni, not far away from the city-wall of Punic origins. ${ }^{111}$

On the basis of available archaeological evidence, it seems that pomegranate did not enjoy in Sardinia the same fortune that it achieved in other western Phoenician regions. The strict relationship established between Phoenician and Punic centres there with Carthage, which is typical of Sardinian culture from the $6^{\text {th }}$ century BC onwards, however, did not trigger the diffusion of the pomegranate in local pictorial art. Conversely, it is the circulation and imitation of a certain kind of Greek choroplastic, devoted to Demeter, which vehiculated the spread of the iconography of this fruit (fig. 12:c). ${ }^{112}$

The attestation of the ways of cultivation of malum granatum (i.e. malum punicum) in Palladius, ${ }^{113}$ who owned agri in Sardinia, in the territory of Neapolis (Othoca, on the southern bank of the Gulf of Oristano), a countryside celebrated for its warm climate and water abundance also known for the cultivation of citron (Citrus medica L.) possibly started already at the times of Carthage.

\subsection{Pomegranate in Phoenician and Punic Sicily}

Since the antiquity, Sicily had the fame of being a feracious land ( $\tau \tilde{\eta} \varsigma \kappa \alpha \lambda \lambda \iota \kappa \alpha ́ \rho \pi o v$

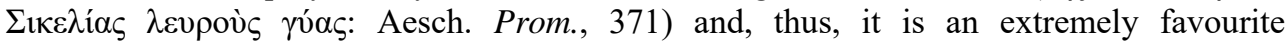
environment for growing a plant representing feracity as pomegranate. There are not data available to know when exactly Punica granatum L. reached Sicily, whether in the $1^{\text {st }}$ millennium BC or earlier.

One of the earliest attestations is in Motya (see below $\S 6$.) in the $8^{\text {th }}$ century BC and refers to a cult context. Pomegranates are apparently absent in the $7^{\text {th }}$ and $6^{\text {th }}$ century $\mathrm{BC}$ from Phoenician tombs of Sicily. However, in the following $5^{\text {th }}$ century BC with cultural Hellenisation they spread over both as pieces of the funerary goods and in iconography. Noticeably, in the $4^{\text {th }}$ and $3^{\text {th }}$ century BC, majestic pomegranates are depicted on the painted funerary stelas from Lylibaeum (fig. 12:d). ${ }^{114}$

The syncretistic process affecting Phoenician Astarte and Greek Demeter ${ }^{115}$ is much strong in Sicily than in Southern Italy, where the eastern Mistress of Animals/Mother Goddess of oriental origins merges with Hera. Sicily was a region devoted to agriculture since millennia, and there the cult of Demeter and Kore achieved a widespread popularity. Its overlapping to Astarte was a natural development and represents a hybridization of the Greek and oriental traditions.

\section{Pomegranate in Motya [LN-FS]}

Motya is amongst the earliest Phoenician foundations in the West. ${ }^{116}$ Pomegranate (Punica granatum L.) seeds were present in the sampled soil from Building $\mathrm{C} 8,{ }^{117}$ the

111 Pesce 1966, 166.

112 Tore 1989, 416. A folk tradition of Sant'Antioco of the Day of the Dead, in the night between the $1^{\text {st }}$ and $2^{\text {nd }}$ of November, is to expose in front of houses doors a cup of milk and a pomegranate as offerings for the deceased.

113 Pall. Opus Agriculturae, V, 4, 4.

114 Vento 2000, 162-163, pls. X, XV, XX, XXXVIII.

115 Ribichini 1995, 9 ff.; Spagnoli 2013, 159-160.

116 Nigro - Spagnoli 2017. 
earliest warehouse erected by Phoenicians when they stably settled on Motya at the beginning of the $8^{\text {th }}$ century $\mathrm{BC}$. Burnt fragments of rind were found in the earliest Phoenician layers of Area D in pit P.1112 of the late $8^{\text {th }}-7^{\text {th }}$ century BC. These finds suggest that the plant arrived at Motya with Phoenicians in the first centuries of the $1^{\text {st }}$ millennium $\mathrm{BC}$, even though the possibility that it reached the island before cannot be fully ruled out. Finding contexts point at ordinary consumption of the fruit; however, a single retrieval from the Temple of Astarte in the Sacred Area of the Kothon also documented about its cultic use.

\subsection{The Temple of Astarte Aglaia [LN]}

In the 2012-2017 seasons, a small temple devoted to Astarte was excavated in the northeastern sector of the so-called Sacred Area of the Kothon, the largest religious compound of the Phoenician colony, occupying the southernmost quadrant of the island, enclosed by a Circular Temenos towards the mid of the $6^{\text {th }}$ century BC. The dedication of the temple to Astarte was indicated by two inscriptions, a Punic and a Greek one, inscribed on later pottery fragments, mentioning respectively LRBT ("the Lady") and AGL[AIA] ("the shining [Goddess]"). ${ }^{118}$

The sacred building had a long history and four successive constructional phases have been excavated so far, a fifth and possibly other earlier stages of the building are still to be investigated. With the construction of the Circular Temenos, the original shrine was shifted towards the south in order to include it fully inside the sacred compound.

In the earliest phase so far explored (Phase 8, Motya IVB, 750-675 BC), a rectangular building was brought to light called "Shrine C12" (fig. 13:a). It measures $8.3 \times 4.1 \mathrm{~m}$ and was entered through a $1.65 \mathrm{~m}$-wide door at the northern extremity of its eastern side, flanked by two protruding half-pillars. The cult focus of the mono-cellular temple was a podium erected at the centre of the short southern side, which possibly supported a cult statue (a bronze earring and a pinecone possibly belonged to a cult figurine were found here: fig. 13:d). ${ }^{119}$ On both sides of the room run two benches, made of mud-bricks, possibly used either as seats or for offerings. Just aside the bottom of the northern side of the western bench, a globular pottery vessel (of a type later called "ink-bottle") was found in situ on the floor.

The vessel was handmade with a grey rough ceramic fabric ( $3 / \mathrm{N}$ very Dark Gray), with a beige clayish coating applied on its outer surface (5Y8/2 Pale Yellow) (fig. 13:b-c). The rim shows a series of oblique indentations resembling the six/seven leaves of the fruit crown. The spherical body was squatted and slightly irregular with the typical shallow recesses of ripe pomegranate. The bottom was flat-cut, with signs of the clay coils. The shape of the vase is a faithful replica of the fruit. Unfortunately, it is not possible to know if there was an outer paint over the beige coating. Similar vases are known in the Phoenician homeland (see above $\S 2$.) and they include those applied on kernoi. The shape indicates the function of container of the vase, which is not a simple replica of the fruit.

\footnotetext{
Nigro 2013, 45.

18 A catalogue of inscriptions to Astarte at Motya in Bonnet 1996, 119-120.

119 Nigro - Spagnoli 2017, 54-55, figs. 19-22.
} 
The vase content was sampled twice and analysed in the Labs of Sapienza University. Data collected suggest that inside the vase there was an organic fluid, leaving traces of iron oxide (pomegranate juice, blood?). The finding spot of the vase points to a use in the temple of the liquid for consumption by worshippers, or libation, or as offering to the Goddess. A possible curative property of the vase content may be also recalled as being consistent with the religious context in an area where sacred springs provided fresh water for healing people.

\subsection{The sacred wells P.2927 and P.1660 [FS]}

Another retrieval of pomegranate in situ occurred in the south-western sector of the Sacred Area of Kothon, inside a well ${ }^{120}$ connected to the cult of Astarte. ${ }^{121}$ Remains of cult activities performed during the $5^{\text {th }}$ century BC were identified in wells P.2927 and P.1660.

The inner fillings of wells contained offerings pointing to a chthonic cult: stone insignia and shells, and, more noticeably from our point of view, seeds of pomegranate, as well as an iron key, and weaving tools which refer to the agrarian and pastoral world. Animal remains which include young pigs, goats, and valuable parts of cows, reflect ritual consumptions of meat.

The analysis of finds suggests a possible connection to the cult of the divine couple Baal - Astarte, the titular deities of the main temples of the Sacred Area since the $8^{\text {th }}$ century BC.

During the $5^{\text {th }}$ century BC, on the wave of cultural Hellenisation, the divine couple Baal - Astarte was assimilated with Poseidon - Demeter, fully fitting into the Sicilian koine. ${ }^{122}$ Astarte is thus worshipped with the attributes and the outfit of Demeter, ${ }^{123}$ as illustrated by some objects found not far from the wells area: a fragmented terracotta representing a female divinity enthroned, holding a pomegranate on her hand (fig. 12:e), ${ }^{124}$ a clay mold of a goddess wearing a polos, ${ }^{125}$ an ivory amulet in the shape of a turtle dove ${ }^{126}$ and, finally, several fragments of iron keys connected to the figure of Demeter as a protector of childbirth. ${ }^{127}$

\section{CONCLUSIONS [LN-FS]}

Across millennia, from the Middle East to the far West of Mediterranean, pomegranate achieved a major role in the economy and ordinary life of ancient peoples, as well as in

120 Phreatic aquifer was collected in a series of wells dug up east of Building C8 since the earliest settlement on the island (Nigro - Spagnoli 2017, 12-17); when the area was refurbished with the erection of the Circular Temenos these installations were re-used for religious purposes.

121 Veronese 2006, 56; Tantillo 2012.

122 Ampolo 2012, 25

123 Syncretic phenomena between Astarte and Demeter are not unusual in Phoenician culture and more generally in the Mediterranean. In the Temple of Astarte at Kition, the goddess is represented as Demeter/Mother goddess on the Greek Red-Figured vases found as offerings and cult-vessels (Chirpanlieva 2010, 188, fig. 1:12-13). A similar syncretism takes place in Etruria where, from the $6^{\text {th }}$ century BC, the Etruscan chthonic deities linked to the nature and the underworld assume the characteristics of Demeter/Ceres, borrowing rites and forms of devotion (Bonamici 2005, 5; Belelli Marchesini et al. 2012, 230, 236).

124 Chiarenza 2015, 55, fn. 27.

${ }_{125}$ Spagnoli 2013, 159; Chiarenza 2015, 53, fn 19; Nigro 2015, 239-240, figs. 16-17; 2016, 44-45.

126 MC.14.188: Barra Bagnasco 2000, 38, fn. 3; D'Anisi 2001a; 2001b, 133; Sznycer 1995, 101.

127 Otto 2007, 307; Gertl 2014, 231. 
symbolic and religious realms in connection with life and death. Each different culture, since the $3^{\text {rd }}$ millennium $\mathrm{BC}$ onwards, found its way to include it into etiological narrations which could explain its numerous positive peculiarities. Pomegranate, with grapes and figs, became a typical fruit of the Levantine, Aegean and Mediterranean societies, as well as a major symbol in afterlife of rebirth and fecundity.

Furthermore, again from the beginning, it was considered a divine fruit and, from this reason it was strictly connected with power, passing from the hands of the gods to those of the kings. In Syria-Palestine it became a typical finial of royal scepters and a regular decorative motive of priests and aristocratic robes and jewelers. Phoenicians and Carthaginians played, also in this case, a determinant role in its diffusion, especially because they transmitted to the West its most ancient oriental meanings and uses, and at the same time, they were able to merge them with significances arriving from the Aegean and Greek world. The golden pome filled up with ruby-red seeds thus became a symbol of prosperity and power which was preserved until nowadays. The sanctuary of the "Madonna del Granato" at Capaccio (Salerno, Italy) near Paestum (fig. 14:a-c), ${ }^{128}$ was erected just upon a Temple of Hera dominating the valley of the Sele river. ${ }^{129}$ There the Holy Mary is portrayed in a painted statue holding a pomegranate as finial of the scepter in her right hand, replicating the sacred gesture and the attribute of the ancient Greek deity.

The fortune of this iconography in the Western World is witnessed by many visual quotations in Medieval and especially Renaissance art, which can be epitomized by Antonello da Messina "Madonna Salting" (fig. 15:a) and Sandro Botticelli's "Madonna della melagrana" in the Uffizi Gallery at Florence (fig. 15:b), where an infant baby Jesus is holding the fruit symbol of life (fig. 15:c), or the sumptuous clothing of Princess Eudoxia decorated by pomegranate blossoms (fig. 15:d), appearing on the masterwork of the end of the $15^{\text {th }}$ century AD, nowadays in the Museu Nacional d'Art de Catalunya at Barcelona ${ }^{130}$.

\section{ABBREVIATIONS}

Add. $^{2}$ T.H. CARPenter - T. MannaCK - M. MendoçA, Beazley Addenda. Additional References to $A B V, A R V^{2}$ \& Paralipomena, Oxford $1989^{2}$.

$\mathrm{ARV}^{2} \quad$ J.D. BEAZLEY, Attic Red-Figure Vase-Painters, Oxford $1963^{2}$.

CVA Berlin 4 N. Kunish, Corpus Vasorum Antiquorum, Berlin Antiquarium 4 (Deutschland 44; Berlin 4), München 1971.

CVA Berlin 12 N. Zimmermann-ElSeIFy, Corpus Vasorum Antiquorum, Berlin Antikensammlung. Attisch Weißgrundige Lekythen (Deutschland 89; Berlin 12), München 2011.

CVA The Hague 1 C.W. Lunsing Scheurleer, Corpus Vasorum Antiquorum, Musée Scheurleer, The Hague 1, (Pays-Bas 1, Musée Scheurleer 1), Paris 1927.

\section{Puca 2014.}

29 In the Heraion at the estuary of the Sele river, a marble statuette representing an enthroned Hera with a cup and a pomegranate in her hands (fig. 14:d) was found (Maddoli 1996, pp. 492-493).

130 "The Exorcism of Princess Eudoxia after the tomb of Saint Stephen" is a panel of an altarpiece including other twelve pieces, possibly painted by master Jaume Vergos II about 1495-1500 AD, now in the in the Museu Nacional d'Art de Catalunya at Barcelona. Here pomegranate is connected to re-birth and healing from demonic possession. It seems noteworthy that in this case the flower of pomegranate decorates the Princess' mantel. 
CVA Kassel 2 P. KRAnZ - R. Lullies, Corpus Vasorum Antiquorum, Kassel, Antikenabteilung Der Staatlichen Kunstsammlungen 2 (Deutschland 38; Kassel 2), München 1975.

CVA Leiden 2 F.M. Vos, Corpus Vasorum Antiquorum, Leiden Rijksmuseun van Oudheden 2. Attic Black-figured Vases (The Netherlands 4; Leiden 2), Leiden 1978.

Para J. D. BeAzLey, Paralipomena. Additions to Attic Black-figure Vase-painters and Attic Red-figure Vase-painters, Oxford 1971.

\section{REFERENCES}

ABRAM, M.

2009 The Pomegranate: Sacred, Secular, and Sensuous Symbol of Ancient Israel: Studia ACQUARO, E. Antiqua 7 (2009), 23-33

2008 Kore nella monetazione di Cartagine punica: C.A. Di Stefano (a cura di), Demetra. La divinità, i santuari, il culto, la leggenda. Atti del I Congresso Internazionale (Enna, 1-4 luglio 2004), Pisa - Roma 2008, pp. 135-136.

Adroher Aurouz, A. - Lopez Marcos, A.

1992 Reinterpretación cronológica de la necrópolis ibérica del Cerro del Santuario (Baza, Granada): Florentia Iliberritana 3 (1992), pp. 9-30.

AlgRAIN, I.

2014 L'alabastre attique. Origine, forme et usages, Brussels 2014

Almagro-Gorbea, M. - Lopez Rosendo, M.E. - Mederos Martin, A. - Torres Ortiz, M.

2010 Los sarcófagos antropoides de la necrópolis de Cádiz: Mainake 32 (2010), pp. 357-394.

AMPOLO, C.

2012 Compresenza di ethne e culture diverse nella Sicilia Occidentale. Per una nuova prospettiva storica: F. BERlinZANi (a cura di), Convivenza etniche, scontri e contatti di culture in Sicilia e Magna Grecia (Aristonothos - Scritti per il Mediterraneo antico, NIC ARAFAT, K. 07), Trento 2012, pp. 15-57.

1990 Classical Zeus. A Study in Art and Literature, Oxford 1990.

ARTZY, M.

1991 Pomegranate scepters and incense stand with pomegranates found in a priest's grave: Biblical Archaeology Review 16,1 (1991), pp. 49-51.

1995 Nami: a second millennium international maritime trading center in the Mediterranean: $\mathrm{S}$. Gitin (ed.), Recent Excavations in Israel: A View to the West (Archaeological Institute of America Colloquia \& Conference Papers 1), Dubuque 1995, pp. 17-40.

AVIGAD, N.

1994 The inscribed pomegranate from the 'House of the Lord': Israel Museum Journal 8 AVRAmidou, A (1994), pp. 7-16.

2011 The Codrus Painter, Iconography and reception of Athenian vases in the age of Pericles, Madison 2011.

Badal García, E. - Bonet Rosado, H. - Collado Mataix, E. - Fabado Alós, F.J. - Fuentes Albero, M. - Izquierdo Peraile, I. - Moreno Martín, A. - Ntinou, M. - QuiXal Santos, D. RiPOLlÈs Alegre, P.P. - SORIA COMBADIERA, L.

2010 Plantas y árboles introducidos: el granado: C. MATA PARREÑo - E. BADAL GARCía - E. Collado MAtAiX - P.P. Ripollès Alegre (eds.), Flora Iberica. De lo real a l'imaginario 
(Servicio de Investigación Prehistórica. Serie de Trabajos Varios, Núm. 111), Valencia 2010, pp. 56-68.

BARNETT, R.D.

1982 Ancient Ivories in the Middle East (QEDEM, Monographs of the Institute of Archaeology, the Hebrew University of Jerusalem 14), Jerusalem 1982.

BARnetT, R.D. - MENDLESON, C.

1987 Tharros. A Catalogue of Material in the British Museum from Phoenician and other Tombs at Tharros, Sardinia (British Museum Publications), London 1987.

BARRA BAGNASCO, M.

1996 L'età lucana. La coroplastica: G. Pugliese CARratelli (a cura di), I Greci in Occidente. Catalogo della Mostra, Palazzo Grassi, Milano 1996, pp. 219-223.

2000 Segni del mondo femminile nei santuari indigeni della Basilicata: M.L. NAVA (a cura di), Ornamenti e lusso. La donna nella Basilicata antica, Roma 2000, pp. 35-39.

BEAZLEY, J.D.

1925 Attische Vasenmaler des rotfigurigen Stils, Tubingen 1925.

Belelli Marchesini, B. - Carlucci, C. - Gentili, D. - Michetti, L.M

2012 Riflessioni sul regime delle offerte nel Santuario di Pyrgi: G.M. Della Fina (a cura di), Il fanum voltumnae e i santuari comunitari dell'Italia antica. Atti del XIX Convegno Internazionale di Studi sulla Storia e l'Archeologia dell'Etruria (Annali della Fondazione per il Museo «Claudio Faina», volume XIX), Roma 2012, pp. 227-263.

BEMMANN, K.

$1994 \quad$ Fullhorner in klassischer und hellenistischer Zeit, Frankfurt 1994.

BIETAK, M.

2009 Near Eastern Sanctuaries in the Eastern Nile Delta: Bulletin d'Archéologie et d'Architecture Libanaises. Hors-Série VI (2009), pp. 209-228.

BIGNASCA, A.M.

2000 I kernoi circolari in Oriente $e$ in Occidente. Strumenti di culto e immagini cosmiche (Orbis Biblicus et Orientalis, 19. Series Archaeologica), Freiburg 2000.

BLÜMEL, C.

1964 Die archaisch griechischen Skulpturen der Staatlichen Museen zu Berlin (Abhandlungen der Deutschen Akademie der Wissenschaften zu Berlin, Klasse für Sprachen, Literatur und Kunst; Jahrg. 1962, nr. 3), Berlin 1964.

BOARDMAN, J.

1989 Athenian Red Figure Vases, The Classical Period, London 1989.

BONAMICI, M.

2005 Appunti sulle pratiche cultuali nel santuario dell'acropoli volterrana: M. BONGHI JOVINO F. CHIESA (a cura di), Offerte dal regno vegetale e dal regno animale nelle manifestazioni del sacro, Atti dell'Incontro di Studio. Milano 26-27 giugno 2003 (Tarchna Supplementum 1), Roma 2005, pp. 1-10.

BONET RosAdO, $\mathrm{H}$.

1995 El Tossal de Sant Miquel de Llíria. La antigua Edeta y su territorio, Valencia 1995.

Bonet Rosado, H. - Mata Perreño, C.

2002 El Puntal dels Llops. Un fortín edetano (Servicio de Investigación Prehistórica. Serie de Trabajos Varios, Núm. 99), Valencia 2002.

BONNET, C.

1996 Astarté. Dossier documentaire et perspectives historiques (Contributi alla Storia della Religione Fenicio-Punica - II. Collezione di Studi Fenici 37), Roma 1996. 
BÖRKER-KLÄHN, F.

1957-1971 Granatapfel: Reallexicon der Assyriologie und Vorderasiatischen Archäologie II, Berlin New York 1957-1971, pp. 610-630.

BotTINI, A.

1996 L'incontro dei coloni greci con le genti anelleniche della Lucania: G. PUGLIESE Carratelli (a cura di), I Greci in Occidente. Catalogo della Mostra, Palazzo Grassi, Milano 1996, pp. 541-548

BURKERT, W.

2010 La religione greca di epoca arcaica e classica (trad. a cura di G. Arrigoni), Milano 2010.

BuRn, L. - GLYNN, R.

1982 Beazley Addenda, Additional References to ABV, $A R V^{2}$, Oxford 1982.

CAMPANELla, L.

2008 Il cibo nel mondo fenicio e punico d'Occidente. Un'indagine sulle abitudini alimentari attraverso l'analisi di un deposito urbano di Sulky in Sardegna (Collezione di Studi Fenici 43), Pisa - Roma 2008.

CARTWRight, C.R.

1997 Interim report on the archaeobotanical material from the 1996 season of excavations of the Early Bronze Age complex at Tell es-Sa'idiyeh, Jordan: Palestine Exploration Quarterly 129 (1997), pp. 72-75.

Chandra, R. - Dhinesh Babu, K. - Tejrao Jadhav, V. - Teixeira da Silva, J.A.

2010 Origin, History and Domestication of Pomegranate: Fruit, Vegetable and Cereal Science and Biotechnology 2010 (special issue), pp. 1-6.

ChiARENZA, N.

2015 Una matrice per terrecotte con sileno dall'area sacra del Kothon a Mozia: Vicino Oriente XIX, 2015, pp. 51-64.

Chirpanlieva, I.

2010 Interpretatio phoenicia. Réinterprétation phénicienne des images représentées sur les vases attiques importés à Kition: Rivista di Studi Fenici 38/2 (2010), pp. 183-201.

COLDSTREAM, J.N.

1995 The Rich Lady of Areiopagos and her Contemporaries: a Tribute in Memory of Evelyn Lord Smithson: Hesperia: The Journal of the American School of Classical Studies at Athens 64 (1995), pp. 391-403.

CRESPI, V.

1868 Catalogo illustrato della raccolta di antichità sarde del Sig. Raimondo Chessa, Cagliari 1868.

D'ANDREA, B

2014 I Tofet del Nord Africa dall'Età Arcaica all'Età Romana (VIII sec. a.C. - II sec. d.C.). D'ANISI, M.C. Studi Archeologici (Collezione di Studi Fenici 45), Pisa - Roma 2014.

2001a Le manifestazioni cultuali: M.L. NAVA - M. OsANNA (a cura di), Rituali per una Dea Lucana. Il Santuario di Torre Satriano, Napoli 2001, p. 127.

2001b Mefite e l'anonima dea del Santuario di Torre Satriano: M.L. NAVA - M. OsANNA (a cura di), Rituali per una Dea Lucana. Il Santuario di Torre Satriano, Napoli 2001, pp. 131134.

De Carthage à Kairouan AA.VV., De Carthage à Kairouan. 2000 and d'art et d'histoire en Tunisie. Musee Du Petit Palais De La Ville De Paris - 20 Octobre 1982 - 27 Fevrier 1983 (Revue du Louvre. La revue des musées de France 32), Paris 1983. 
DE FAVERI, C.

2007 Melograno: M.L. NAVA - M. OSANNA - C. DE FAVERI, Antica flora lucana. Il repertorio DE Miro, E. storico-archeologico, Potenza 2007, pp. 155-167.

2008 Thesmophoria di Sicilia: C.A. Di STEFAno (a cura di), Demetra. La divinità, i santuari, il culto, la leggenda. Atti del I Congresso Internazionale (Enna, 1-4 luglio 2004), Pisa Roma 2008, pp. 47-92.

DE VINCENZO, S.

2012 Tra Cartagine e Roma: I centri urbani dell'eparchia punica di Sicilia tra VI e I sec. a.C. (Topoi: Berlin Studies of the Ancient World 8), Berlin 2012.

FATEH, M.V. - AHMED, S. - Ali, M. - BANDYOPADHYAY, S.

2013 A Review on the Medicinal Importance of Pomegranate: Rajiv Gandhi University of Health Sciences Journal of Pharmaceutical Sciences 3 (2013), pp. 23-25.

FERRON, J.

1958-1959 Le médaillon de Carthage: Cahiers de Byrsa 8 (1958-1959), pp. 45-56.

1968 Le problème du médaillon de Carthage: Le Muséon, Revue d'Etudes Orientales 81 (1968), pp. 255-261.

FOSTER, J.L.

1992 Love Songs of the New Kingdom, Austin 1992.

Fox, W.S.

1916 Greek and Roman Mythology (Mythology of all Races I), Boston, 1916.

FRUMIN, S. - WeISS, E.

2018 Plant use in the Bronze and Iron Age at Tell es-Sâfi/Gath: Near Eastern Archaeology 81.1

GAIS, R.M (2018), pp. 77-80.

1978 Some Problems of River-God Iconography: American Journal of Archaeology 82/3 (1978), pp. 355-370.

GARCÍA CANO, J.M.

1997 Las necrópolis ibéricas de Coimbra del Barranco Ancho (Jumilla, Murcia). I. Las GertL, V. excavaciones y estudio analítico de los materiales, Murcia 1997.

2014 Acque risorgive, pozzi sacri e pratica rituale nel Santuario di Demetra a Policoro, MT (Herakleia in Lucania): Memorie Descrittive della Carta Geologica d'Italia 46 (2014), pp. 227-238.

GHAKI, M.

1992-1993 Les steles d'El Ghzaizya: Revue des Études Phéniciennes - Puniques des Antiquités Libyques 7-8 (1992-1993), pp. 165-177.

GoOR, A.

1967 The History of the Pomegranate in the Holy Land: Economic Botany 21/3 (1967), pp. 215-230.

HALDANE, C.

1993 Direct evidence for organic cargoes in the Late Bronze Age: World Archaeology 24 (1993), pp. 48-60.

HEPPER, F.N.

1990 Pharaoh's Flowers: The Botanical Treasures of Tutankhamun, London 1990.

Hopf, M.

1969 Plant remains and early farming in Jericho: P.J. UCKO - C.W. DimBLEBY (eds.), The Domestication and Exploitation of Plants and Animals, London 1969, pp. 355-359. 
1978 Plant remains, Strata V-I: R. AmIRAN (ed.), Early Arad, Vol. 1 (Israel Exploration Society), Jerusalem 1978, pp. 64-82.

HORUS-MiEDAN, M.

1951 Les représentations figures sur les stèles de Carthage: Cahiers de Byrsa 1 (1951), pp. 15160.

HusSEIN, M.M.

2016 Nimrud. The Queen's Tombs (Oriental Institute Miscellaneous Publications), Chicago 2016.

IMMERWAHR, S.A.

1989 The pomegranate vase: its origins and continuity: Hesperia: The Journal of the American School of Classical Studies at Athens 58/4 (1989), pp. 397-410.

IZQUIERDO, I.

1997 Granadas y adormideras en la cultura ibérica y el contexto del mediterráneo antiguo: Pyrenae 28 (1997), pp. 65-98.

KARAGEORGHIS, V.

2002 Early Cyprus. Crossroads of the Mediterranean, Milano 2002.

KENYON, K.M.

$1960 \quad$ Excavations at Jericho I. The Tombs excavated in 1952-1954, London 1960.

KOKAJ, T. - ÇAKALLI, A.D. - ISMAILI, H.

2017 IBA for rooting influence of some varieties of pomegranate (Punica granatum L): Albanian journal of agricultural sciences 2017, pp. 133-137.

LAMON, R.S. - SHIPTON, G.M.

1939 Megiddo, I. Season 1925-34. Strata I-V (Oriental Institute Publications 42), Chicago 1939.

LANCEL, $\mathrm{S}$

1992 Carthage, Paris 1992.

LEMAIRE, A.

1981 Une inscription paléo-hébraïque sur grenade en ivoire: Revue Biblique 88 (1941) pp. 236239.

1984 Probable Head of Priestly Scepter from Solomon's Temple Surfaces in Jerusalem: Biblical Archaeology Review 10.1 (1984), pp. 24-29.

LEVI, D.

1949 Le necropoli puniche di Olbia: Studi Sardi 9, 1949, pp. 5-120.

LIPPOLIS, E. - PARISI, V.

2012 La ricerca archeologica e le manifestazioni rituali tra metropoli e apoikiai; AA.VV., "Alle origini della Magna Grecia. Mobilità, migrazioni, fondazioni” (Taranto, 1-4 ottobre 2010), Atti del Cinquantesimo Convegno di Studi sulla Magna Grecia, Taranto 2012, pp. 423-455.

LIPSCHITZ, O.

1989 Plant economy and diet in Early Bronze Age in Israel: a Summary: P. DE MiroschedJI (ed.), L'urbanisation de la Palestine à l'âge du Bronze Ancien. Bilan et perspectives des recherches actuelles, Actes du colloque d'Emmaüs (20-24 octobre 1986) (British Archaeological Reports International Series 527), Oxford 1989, pp. 269-277.

LORET, V.

1892 La flore pharaonique d'après la documentation hiéroglyphique et les spécimens découverts dans les tombes, Paris 1892

LOUD, G.

1948 Megiddo, II. Seasons of 1935-39 (Oriental Institute Publications 62), Chicago 1948. 


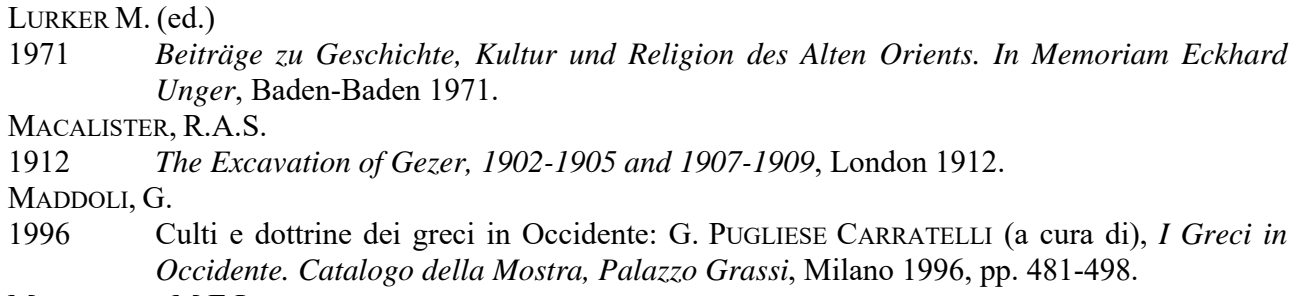

1981 La necrópolis ibérica de la Bobadilla (Jaén): J. MALUQuer - M.E. AubEt (eds.), Andalucía y Extremadura. Programa de investigaciones protohistóricas dirigido por Juan Maluquer de Motes (Departamento de Prehistória y Arqueologia), Barcelona 1981, pp. 1-52.

MANDIČ, J. - VITA, C.

2014 Le comunità dell'entroterra: il caso di San Brancato di Sant'Arcangelo (PZ). La necropoli lucana: F. MeO - G. Zuchtriegel (eds.), Siris, Herakleiaa, Poluchoron. Città e campagna tra antichità e medioevo. Atti del Convegno (Policoro, 12 luglio 2013) (Siris 14), Bari 2014, pp. 203-213.

MARAZZI, M.

2003 The Mycenaeans in the Western Mediterranean $\left(17^{\text {th }}-13^{\text {th }}\right.$ c. BC): N.CHR. STAMPOLIDIS (ed.), Sea routes... From Sidon to Hulelva. Interconnections in the Mediterranean $16^{\text {th }}-6^{\text {th }}$ c. BC, Athens 2003, pp. 108-115.

Marchetti, N. - PeKer, H.

2018 The Stele of Kubaba by Kamani and the Kings ofKarkemish in the 9th Century BC: Zeitschrif für Assyriologie 108/1 (2018), pp. 81-99.

mata Parreño, C. - Badal García, E.- Bonet Rosado, H. - Collado Mataix, E. - Fabado Alós, F.J. - Fuentes Albero, M. - Izquierdo Peraile, I. - Moreno Martín, A. - Ntinou, M. - Quixal SANTOS, D. - RiPollès Alegre, P.P. - SoRia COMBADIERA, L.

2007 De lo real a l'imaginario. Approcimación a la flora ibérica durante la edad del hierro: Anales de Arqueología Cordobesa 18 (2007), pp. 93-122.

2010 Comida para la eternidad: Saguntum Extra. Papeles del Laboratorio de Arqueología de Valencia 9 (2010), pp. 277-286.

MatThiae, $\mathrm{P}$.

1993 L'aire sacrée d'Ishtar à Ebla: Résultats des fouilles de 1990-1992: Comptes-Rendus des seances de l'Académie des Inscriptions et Belles-Lettres 1993, pp. 613-662.

2002 Tell Mardikh, 1977-1996: Vingt Ans de Fouilles et de Découvertes. La Renaissance d'Ebla Amorrheenne: Akkadica 101 (2002), pp. 1-29.

MAVROMATI A.

2017 Landscape and wood-fuel in Akrotiri (Thera, Greece) during the Bronze Age: Quaternary International 458 (2017), pp. 44-55.

MAZAR, A.

1980a Excavations at Tel Qasile Part One. The Philistine Sanctuary: Architecture and Cult Objects (QEDEM, Monographs of the Institute of Archaeology, the Hebrew University of Jerusalem, 12), Jerusalem 1980.

1980b Excavations at Tel Qasile Part Two. The Philistine Sanctuary: Various Finds, The Pottery, Conclusions, Appendixes (QEDEM, Monographs of the Institute of Archaeology, the Hebrew University of Jerusalem, 12), Jerusalem 1980. 
MEIRANO V.

1996 Frutti, dolci e focacce in area metapontina: la documentazione coroplastica: Bollettino Storico della Basilicata 12 (1996), pp. 67-102.

MOORTGAT-CORRENS, U.

1989 La Mesopotamia (Storia Universale dell'Arte, sezione prima: le civiltà antiche e primitive, diretta da Sabatino Moscati), Torino 1989.

Moscati, S. - UBerti, M.L.

1987 Iocalia punica. La collezione del Museo Nazionale G.A. Sanna di Sassari (Memorie dell’Accademia Nazionale dei Lincei 29, serie $8^{\circ}$ ), Roma 1987.

MURRAY, M.A.

2000 Fruits, vegetables, pulses and condiments: P.T. NichOLSON - I. SHAW (eds.), Ancient Muthmann, F. Egyptian Materials and Technology, Cambridge 2000, pp. 609-655.

1982 Der Granatäpfel: Symbol des Lebens in der alten Welt, Fribourg 1982.

NigRO, L.

1994 Ricerche sull'architettura palaziale della Palestina delle Età del Bronzo e del Ferro. Contesto archeologico e sviluppo storico (Contributi e Materiali di Archeologia Orientale, 5), Roma 1994.

2013 Before the Greeks: the earliest Phoenician settlement in Motya - recent discoveries by Rome «La Sapienza» Expedition: Vicino Oriente XVII (2013), pp. 39-74.

2015 Mozia tra VI e V secolo a.C. Monumentalizzazione e organizzazione socio-politica: un nuovo modello: M.P. BAGLione - L.M. MichetTi (a cura di), Le lamine d'oro a cinquant'anni dalla scoperta. Dati archeologici su Pyrgi e rapporti con altre realtà del Mediterraneo (Scienze dell'Antichità 21.2), Roma 2015, pp. 225-245.

2016 L'approdo delle meraviglie: Archeo 378, agosto 2016, pp. 36-49.

NigRo L. - SpaGnOLI, F.

2017 Landing on Motya. The earliest Phoenician settlement of the $8^{\text {th }}$ century BC and the creation of a West Phoenician cultural identity in the excavations of Rome «La Sapienza» University - 2012-2016. Stratigraphy, architecture, and finds (Quaderni di Archeologia Fenicio-Punica/Colour Monograph 04), Rome 2017.

ORENDI, A. - DECKERS, K.

2018 Agricultural resources on the coastal plain of Sidon during the Late Iron Age: archaeobotanical investigations at Phoenician Tell el-Burak, Lebanon: Vegetation History and Archaeobotany 2018, pp. 1-20.

ORLANDINI, P.

1983 Le arti figurative: G. Pugliese Carratelli (a cura di), Megale Hellas. Storia e civiltà della Magna Grecia, Milano 1983, pp. 481-557.

Отто, В

2007 Il santuario di Demetra ad Heracleia Lucania: Elementi comuni con il mondo indigeno: E. Christof - G. KoINer - M. LehNER - E. Pochmarski (Hrsg.), Potnia Theron. Festschrift für Gerda Schwarz zum 65. Geburtstag (Veröffentlichungen Des Instituts für Archäologie der Karl-Franzens-Universität Graz, band 8), Wien 2007, pp. 305-308.

PARISI, V.

2017 I depositi votivi negli spazi del rito. Analisi dei contesti per un'archeologia della pratica cultuale nel mondo siceliota e magnogreco (Supplementi e Monografie della rivista "Archeologia Classica", 14 - n.s. 11), Roma 2017.

Pereira, L. - Chapa, T. - Madrigal, A. - Uriarte, A. - Mayoral, V. (eds.)

2004 La necrópolis ibérica de Galera (Granada). La colección del Museo Arqueológico Nacional, Madrid 2004. 
Pérez-Jordà, G. - Peña-Chocarro, L. - García Fernández, M. - Vera Rodríguez, J.C.

2017 The beginnings of fruit tree cultivation in the Iberian Peninsula: plant remains from the city of Huelva (southern Spain): Vegetation History and Archaeobotany 26/5 (2017), pp. 527-538.

Pesce, G.

1961 Sardegna punica, Cagliari 1961.

1966 Tharros, Cagliari 1966.

PONTRANDOLFO, A.

1996 La pittura parietale in Magna Grecia: G. Pugliese CARRATElli (a cura di), I Greci in Occidente. Catalogo della Mostra, Palazzo Grassi, Milano 1996, pp. 457-470.

Pontrandolfo, A. - Rouveret, A.

$1992 \quad$ Le tombe dipinte di Paestum, Modena 1992.

PRESEDO, F.J.

1982 La necrópolis de Baza (Excavaciones Arqueológicas en España 119), Madrid 1982.

PUCA, G.

2014 La montagna che parla. La Madonna del Granato sul monte Calpazio, Eboli 2014.

RIBICHINI, S.

1995 Flebili dee fenicie: Rivista di Studi Fenici 23 (1995), pp. 3-35.

2015 Statue greche e culti fenici: C. Giuffre ScibOnA - A. MASTROCINQUE - A. Multari (edd.), Ex pluribus unum. Studi in onore di Giulia Sfameni Gasparro, Roma 2015, pp. 157-167.

RIEZLER, W.

$1914 \quad$ Weißgrundige Attische Lekythen, Münich 1914.

RuSSO, A. - VICARI SOTTOSANTI, M.A.

2009 Tra Enotri e Lucani: le necropoli del V e IV secolo a.C. in località Tempa Cagliozzo di San Martino d'Agri (PZ): FastiOnLine 139, www.fastionline.org/docs/FOLDER-it-2009139.pdf.

SCHMANDT-BESSERAT, D.

1992 Before Writing: From Counting to Cuneiform, Austin 1992.

SFAMENI GASPARRO, G.

2008 Demetra al confine tra Greci e Punici: osservazioni sul culto della Malophoros a Selinunte: M. Congiu - C. Miccichè - S. Modeo - L. Santagati (a cura di), Greci e SPAGNOLI, F Punici in Sicilia tra il V e il IV secolo a.C., Caltanissetta - Roma 2008, pp. 101-120.

2013 Demetra a Mozia: evidenze dell'area sacra del Kothon nel V secolo a.C.: Vicino Oriente XVII (2013), pp. 153-165.

SZNYCER, M.

1995 La religion punique à Carthage: Carthage, l'histoire, sa trace et son écho (Les Musées de la ville de Paris, Musée du Petit Palais, 9 mars, 2 juillet 1995), Paris 1995, pp. 100117.

TANTILLO, I.

2012 Alcune riflessioni sull'organizzazione spaziale dei santuari demetriaci periferici delle poleis siceliote in Età Arcaica: V. Nizzo - L. LA RoccA (a cura di), Antropologia e archeologia a confronto: rappresentazioni e pratiche del sacro. Atti del secondo Incontro Internazionale di studi, Roma, Museo Nazionale Preistorico Etnografico "Luigi Pigorini”, 20-21 maggio 2011 (Antropologia e archeologia a confronto 2), Roma 2012, pp. 641-652. 
THOMPSON, S

1955-1958 Motif-index of folk-literature: a classification of narrative elements in folktales, ballads, myths, fables, medieval romances, exempla, fabliaux, jest-books, and local legends, Revised and enlarged edition. Bloomington: Indiana University Press, 1955-1958.

TORE, G.

1989 Sardinia Antiqua. Saggio di bibliografia fenicio-punica: Biblioteca Francescana Sarda 2 (1989), pp. 229-427.

TORRES GOMARIZ, O.

2017 La Granada: usos y significados de una fruta de oriente en occidente: F. Prados Martínez - F. SAla Sellés (eds.), El Oriente de Occidente. Fenicios y Púnicos en el área ibérica. VIII edición del Coloquio Internacional del CEFYP en Alicante, Alicante 2017, pp. 625-640.

TUFNELL, O

1958 Lachish IV (Tell ed- Duweir). The Bronze Age (The Welcome Marston Archaeological Research Expedition to the Near East), London 1958.

UBERTI, M.L.

1975 Le terrecotte: E. ACQUARO - S. MosCATI - M. L. UberTi (eds.), Anecdota Tharrhica, Roma 1975, pp. 17-50.

1977 Le terrecotte: E. Acquaro - S. Moscati - M.L. Uberti (eds.), La Collezione Biggio. Antichità puniche a Sant'Antioco, Roma 1977, pp. 29-36.

VAN ZEIST, W.V. - BOTTEMA, S.

1982 Vegetational history of the Eastern Mediterranean and the Near East during the last 20.000 years: J.L. BinTLIFF - W.V. VAN Zeist (eds.), Palaeoclimates, Palaeoenvironments and Human Communities in the Eastern Mediterranean Region in Later Prehistory (British Archaeological Reports. International Series 133), Oxford 1982.

VAN ZeIST, W.V. - BOTTEMA, S. - VAN DER VEEN, M.

2001 Diet and vegetation at Ancient Carthage: the archaeobotanical evidence, Groninga 2001.

VENTO, M.

$2000 \quad$ Le stele dipinte di Lilibeo, Trapani 2000.

VERONESE, F.

2006 Lo spazio e la dimensione del sacro. Santuari greci e territorio nella Sicilia arcaica (Saggi di antichità e tradizione classica 24, nuova serie), Padova 2006.

WACHTER-SARKADY, C.

1995 Ebla e le condizioni materiali della produzione agricola nell'antico Oriente: P. MATTHIAE - F. Pinnock - G. ScAndone Matthiae (eds.), Ebla: Alle origini della civiltà urbana Milano: Electa, pp. 242-251.

WARD, C.

2003 Pomegranates in Eastern Mediterranean contexts during the Late Bronze Age: World Archaeology 34/3 (2003), pp. 529-541.

Xella, P.

1969 Sull'introduzione del culto di Demetra e Kore a Cartagine: Studi e materiali di storia delle religioni 40 (1969), pp. 215-228.

ZOHARY, D. - SPIEGEL-ROY, P.

1975 Beginnings of fruit growing in the old world: Science 187 (1975), pp. 319-327. 


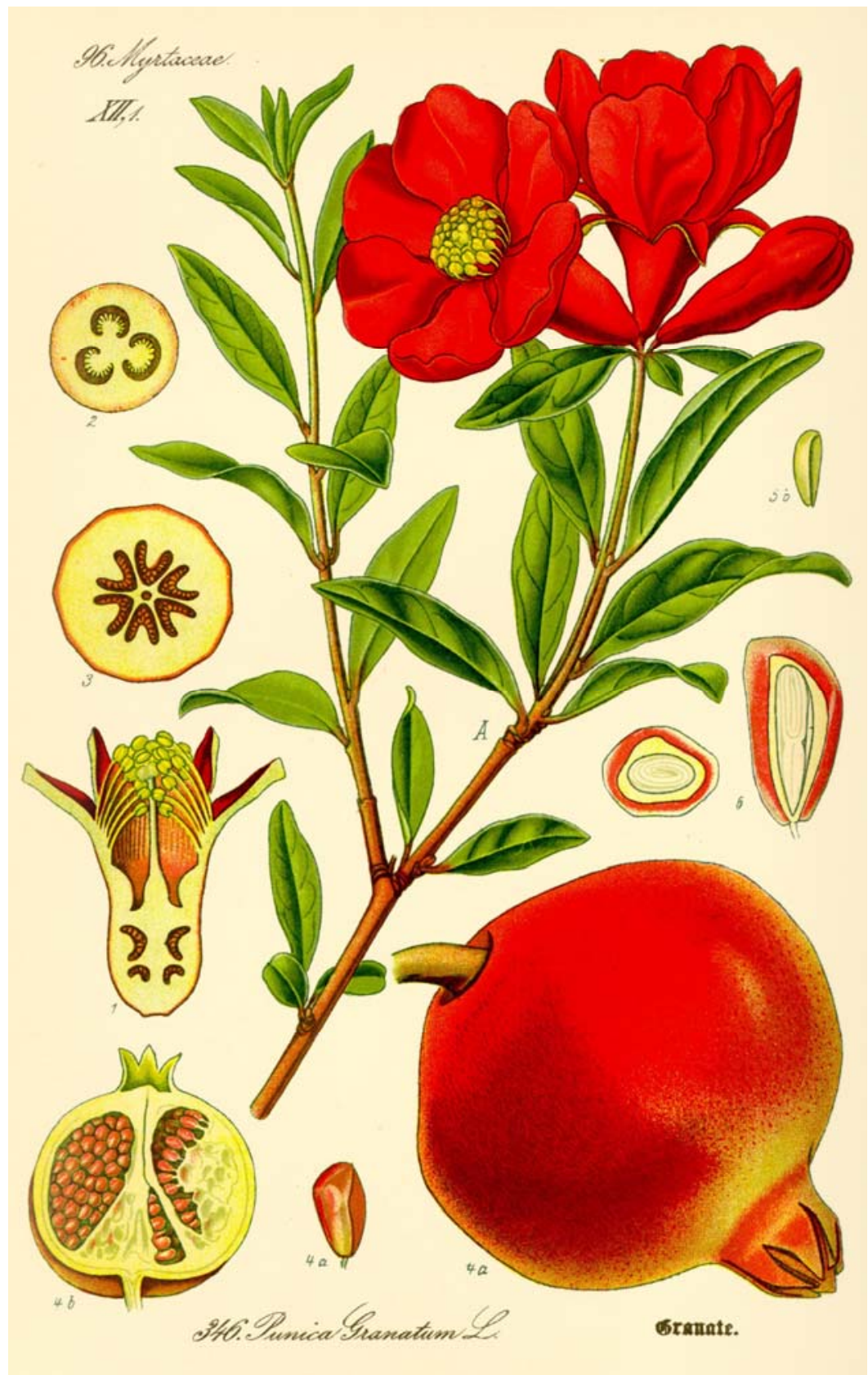

Fig. 1 - Plant and fruit of pomegranate from an $18^{\text {th }}$ century AD herbarium. 

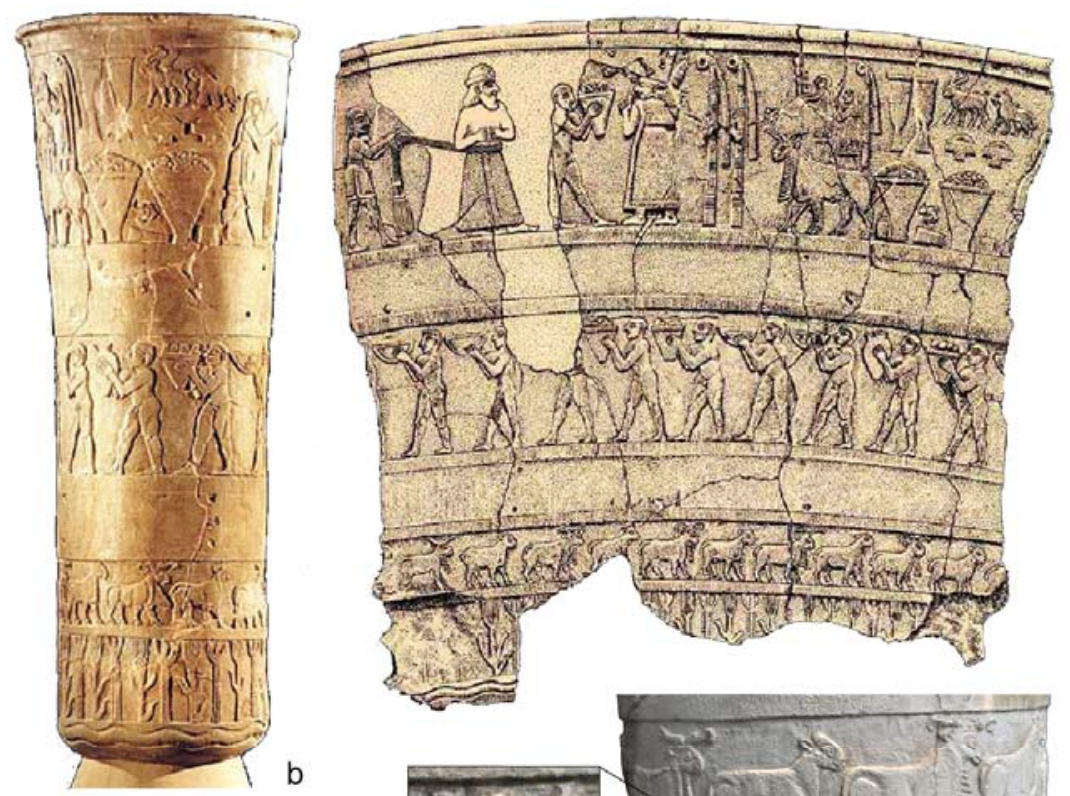

b
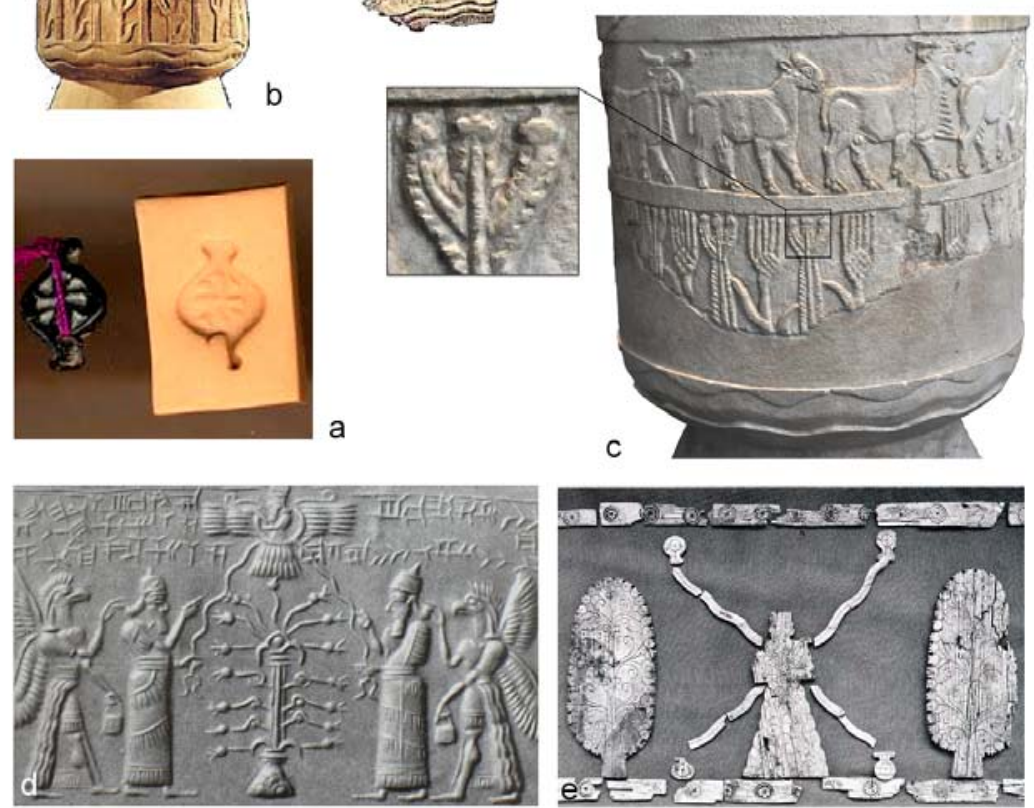

Fig. 2 - Mesopotamia: a - hematite stamp seal of the Late Uruk period representing a schematic pomegranate fruit (3300-3100 BC); b-c - carved alabaster vase from Uruk-Warka (3500-3300 BC); in the lower register (c), three branches pomegranate trees; $\mathrm{d}$ - NeoAssyrian cylinder seal impression showing a couple of kings and eagle-headed winged genia performing ritual aspersion of a pomegranate bush as Tree of Life; $d$ - Middle Assyrian ivory inlays from a box representing the God of the gushing water flanked by pomegranate trees $\left(13^{\text {th }}\right.$ century $\left.\mathrm{BC}\right)$. 

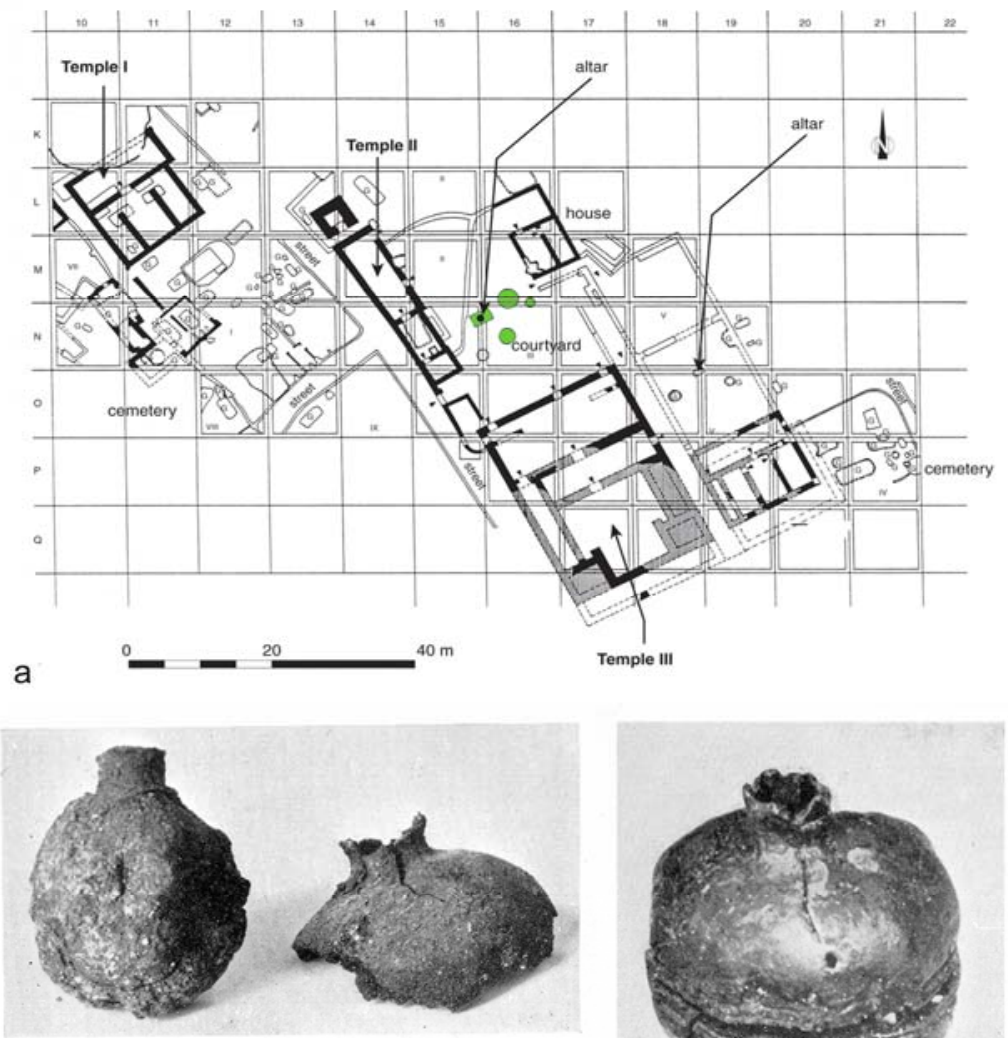

b
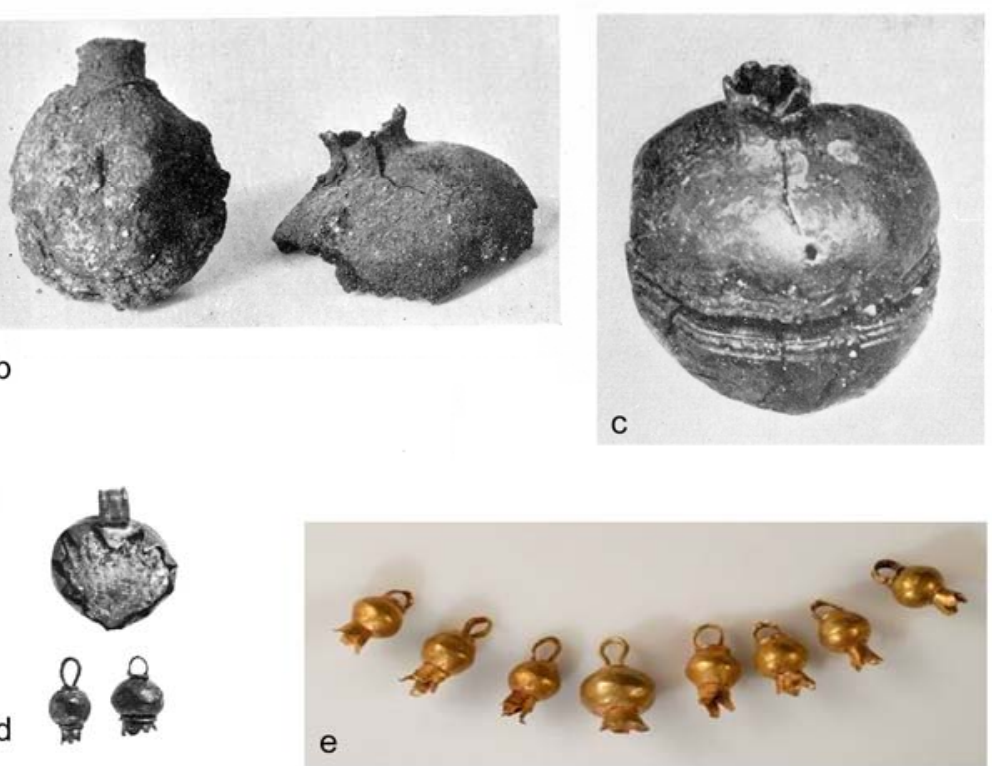

Fig. 3 - Middle-Late Bronze Age Levant: a - plan of Temple III at Tell ed-Dab'a in the Eastern Nile Delta. Seeds of pomegranate were found in the courtyard (in green); b desiccated pomegranate fruits from Tomb B35 at Jericho (MB IIB); c - pomegranateshaped wooden box from Tomb 35 Jericho (MB IIB); $d$ - pendants in shape of pomegranate from Megiddo found in Palace 2041, "Treasure 3073" (Late Bronze Age IIB, stratum VIIA); e - Golden pomegranate pendants on exhibit in the Israel Museum, Jerusalem. 


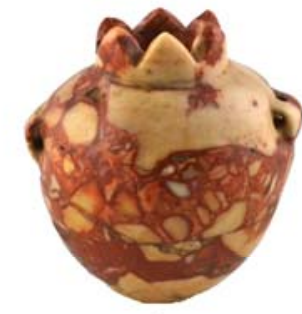

a

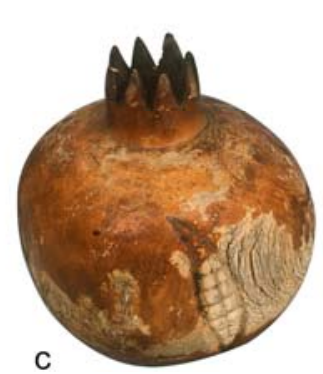

C

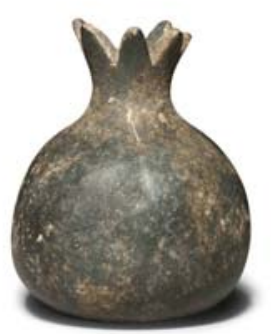

b
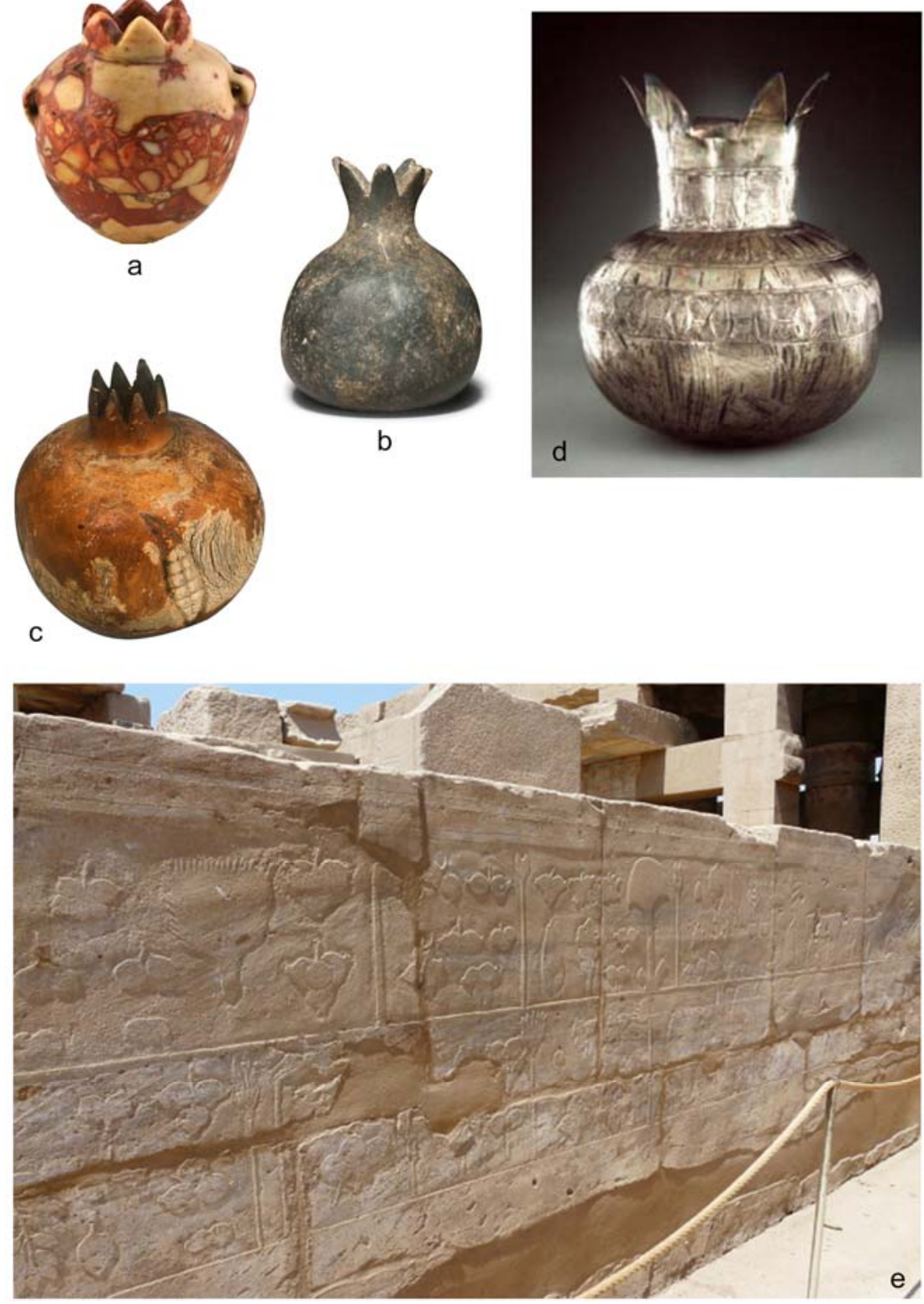

Fig. 4 - Egypt: a - breccia miniature stone jar of Proto-Dynastic period in the shape of a pomegranate. Note that the colour of the stone resembles that of the original blossom; the shape is that of Punica protopunica L.; b-c - steatite and ivory replicas of pomegranate from the Tomb of Tutankhamon; $d$ - silver pomegranate-shaped ritual vessel from the Tomb of Tutankhamon; e - the "Syrian Garden" wall relief of Thutmose III at Karnak. 

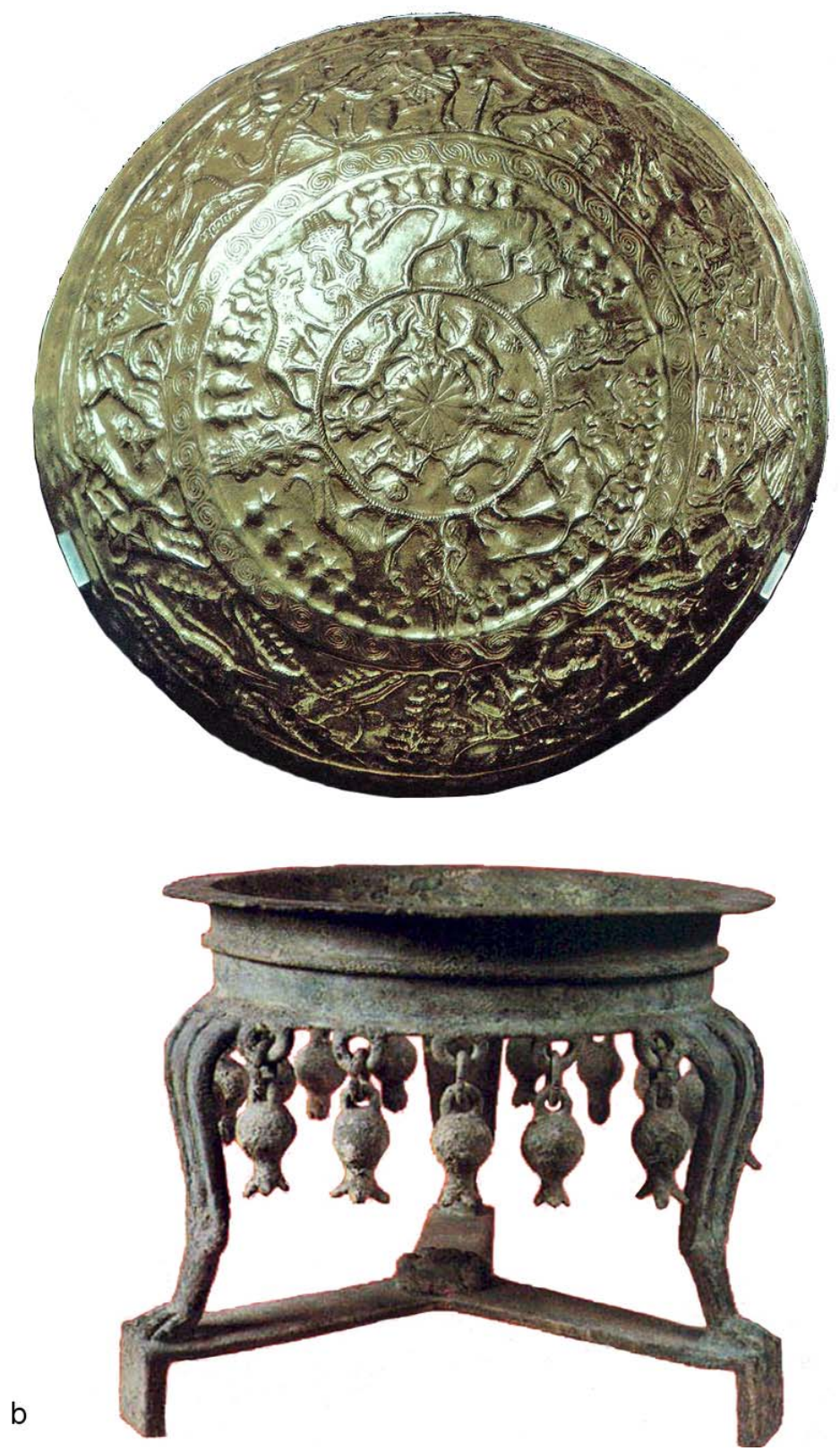

Fig. 5 - Ugarit: a - golden hemispherical bowl found in the Temple of Baal with chiselled pomegranates garland; $b$ - bronze stand for incense-burner with pomegranate pendants as decorations. 

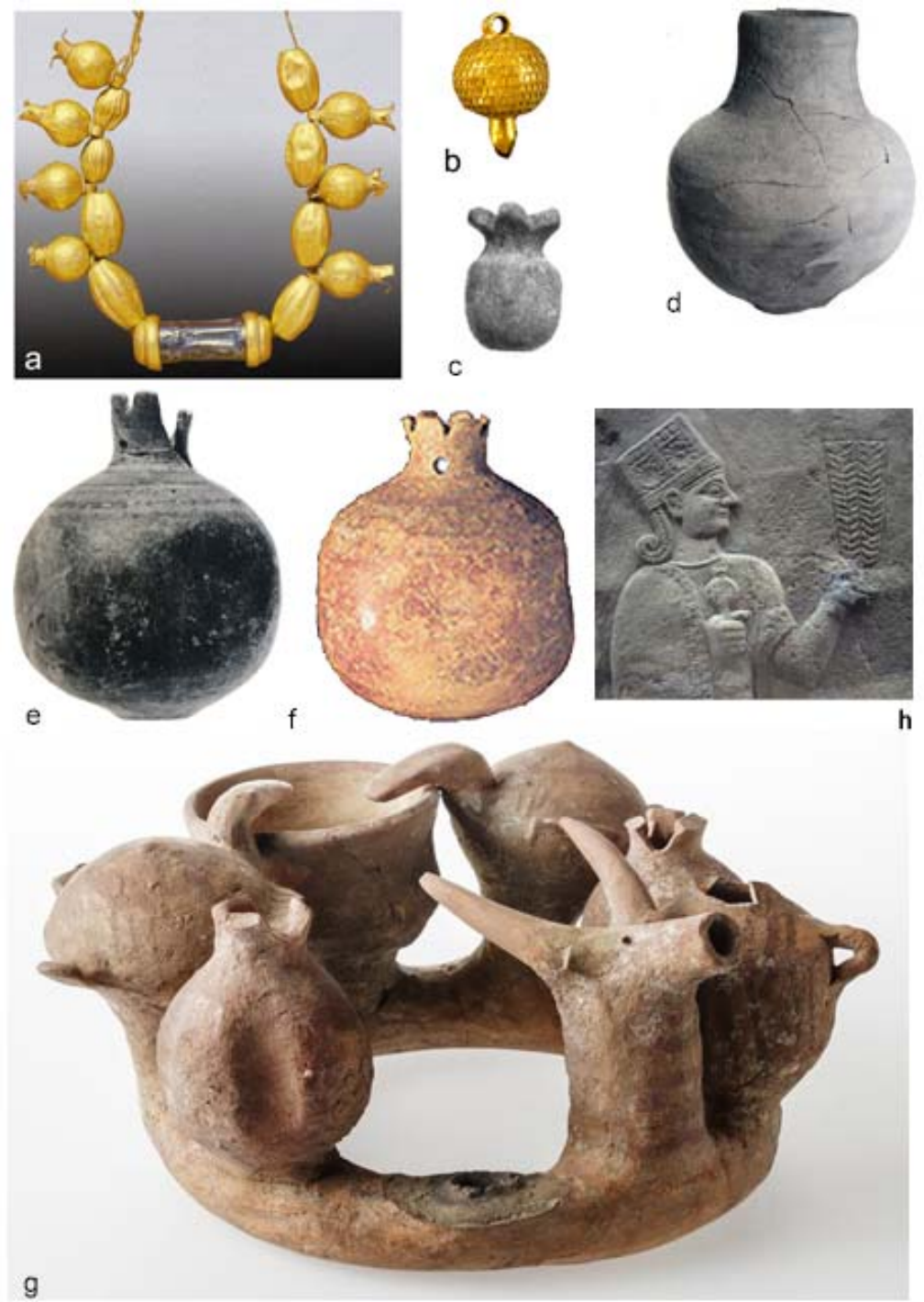

Fig. 6 - Late Bronze - Iron Age Levant and Cyprus: a - golden necklace from Ayios Iakovos, Cyprus; $\mathrm{b}$ - golden pendant in the form of pomegranate decorated with rows of granulated triangles from Enkomi tomb (13 ${ }^{\text {th }}$ century BC); c - ivory sceptre finial in shape of pomegranate from Megiddo, stratum IV (Iron IIB); d - pomegranate-shaped vessel (globlet) from Tell Qasile, Building L; e-f - pomegranate shaped vessels with red-slipped surface and black painted bands from Temple 131 at Tel Qasile; g - circular kernos from Megiddo (stratum VI); h - Stela of Kubaba (detail), Karkemish Museum of Anatolian Civilization, Ankara. 

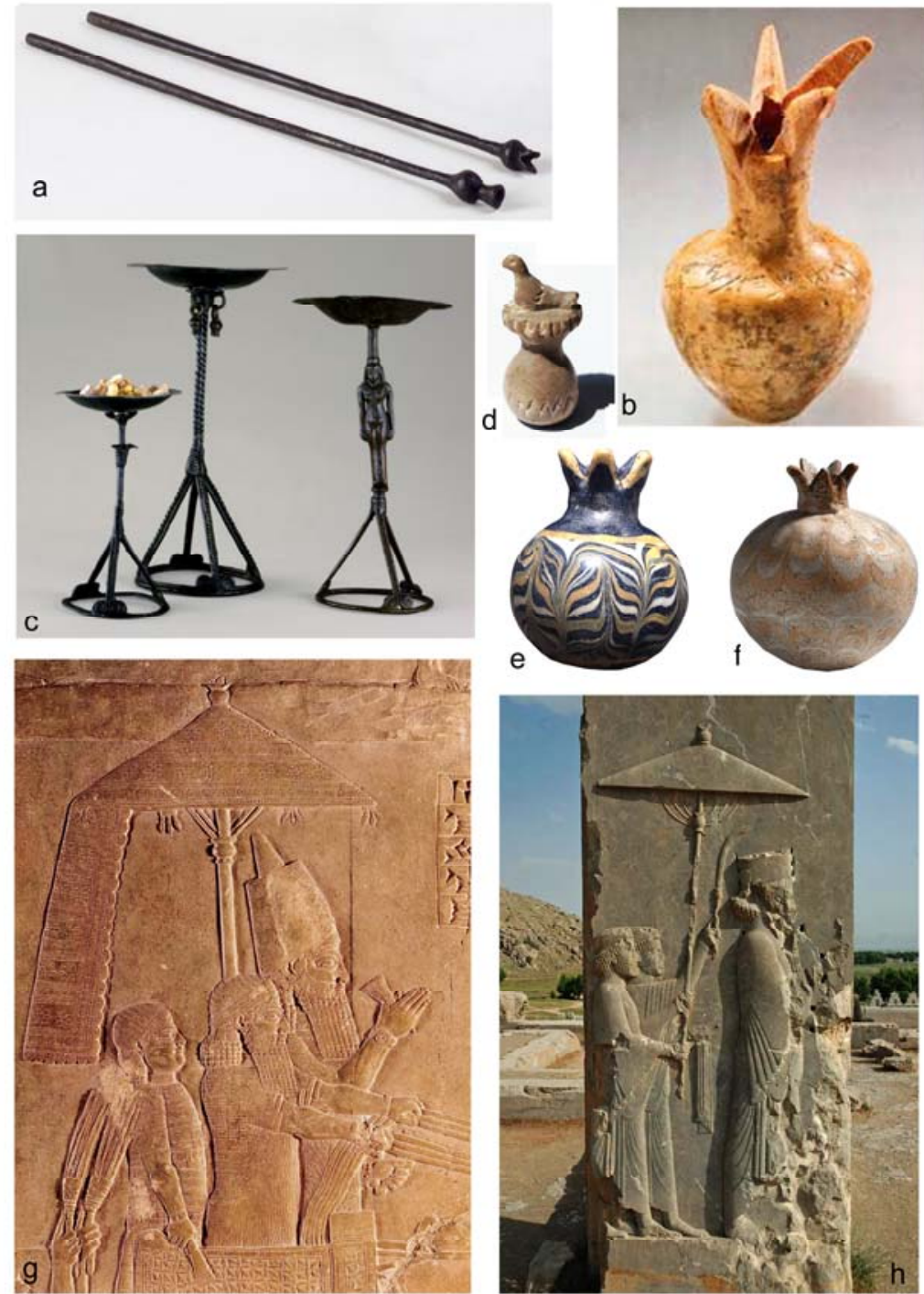

Fig. 7 - Iron Age Levant and Mesopotamia: a - bronze sceptres with pomegranate finials from Tell en-Nami; $b$ - ivory pomegranate from the illegal market of antiquities, Israel Museum, Jerusalem ( $8^{\text {th }}$ century BC); c - bronze thymiaterion from Tell en-Nami with decorative pomegranate pendants; $d$ - ivory pomegranate finial with a dove on the top, Israel Museum, Jerusalem; e-f - Phoenician glass models of pomegranate, Israel Museum, Jerusalem; $g$ - Nineveh, wall relief from the Northern Palace of Assurbanipal representing the King under an umbrella with pomegranate like finials and locks; $h$ - Persepolis, wall relief showing King Xerxes under a shadow umbrella of Assyrian type. 

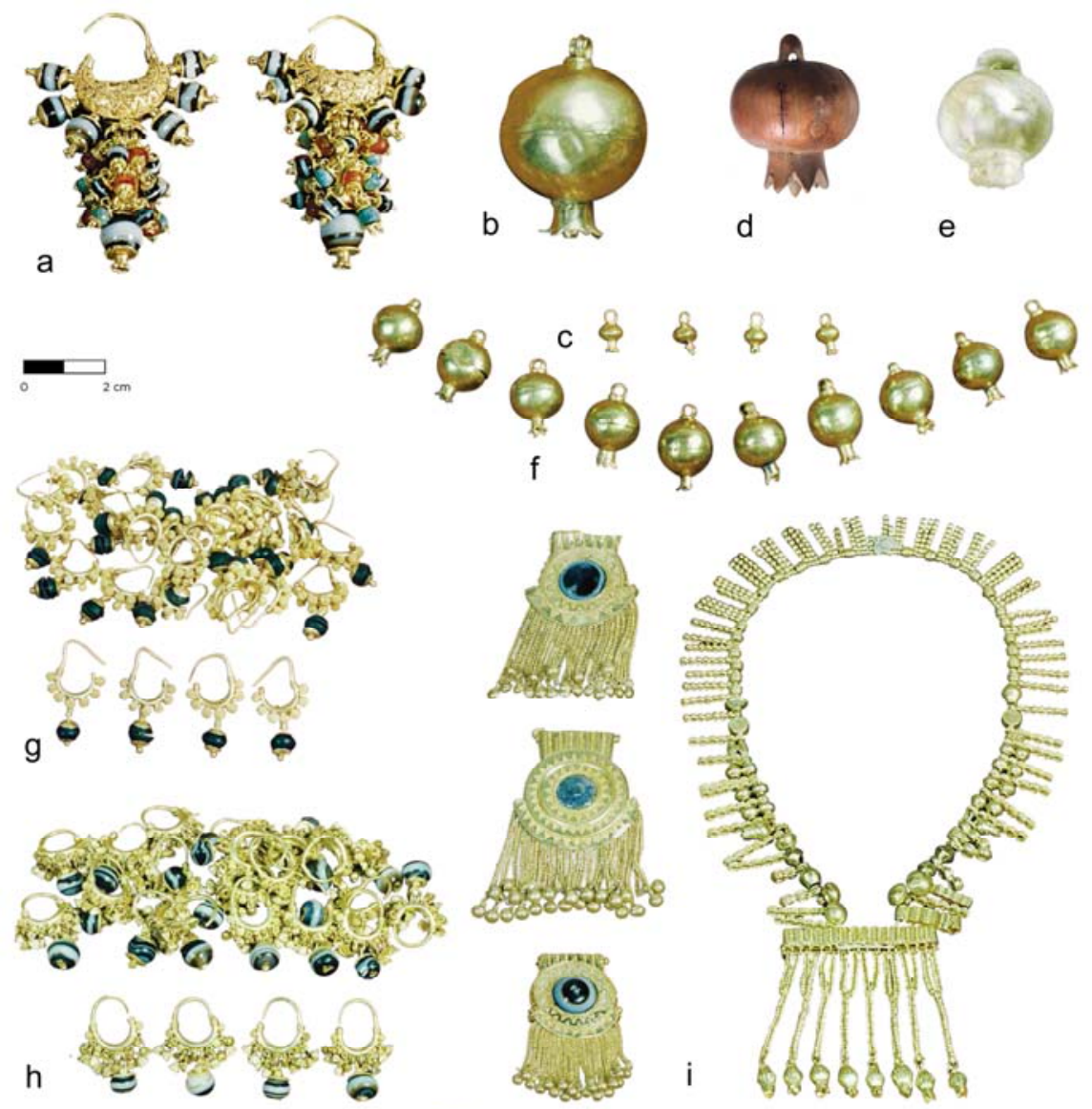

$\mathrm{h}$
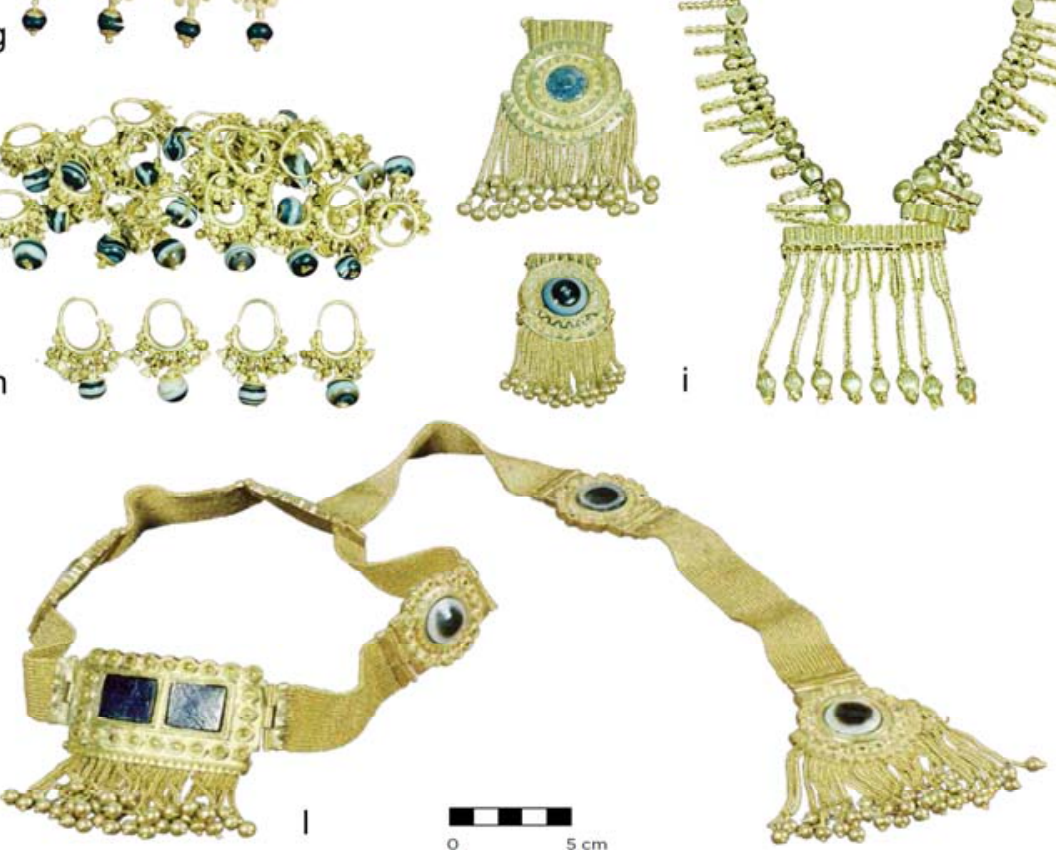

Fig. 8 - Nimrud: jewellery from the Queens' tombs discovered underneath the North-West Palace of Ashurnasirpal II: a, g, h - golden earrings with agate pendants; b, c, f - golden pomegranate-shaped pendant; d-e - votive pomegranate models respectively of ivory and rock crystal; i-1 - golden diadems with agate insets. 

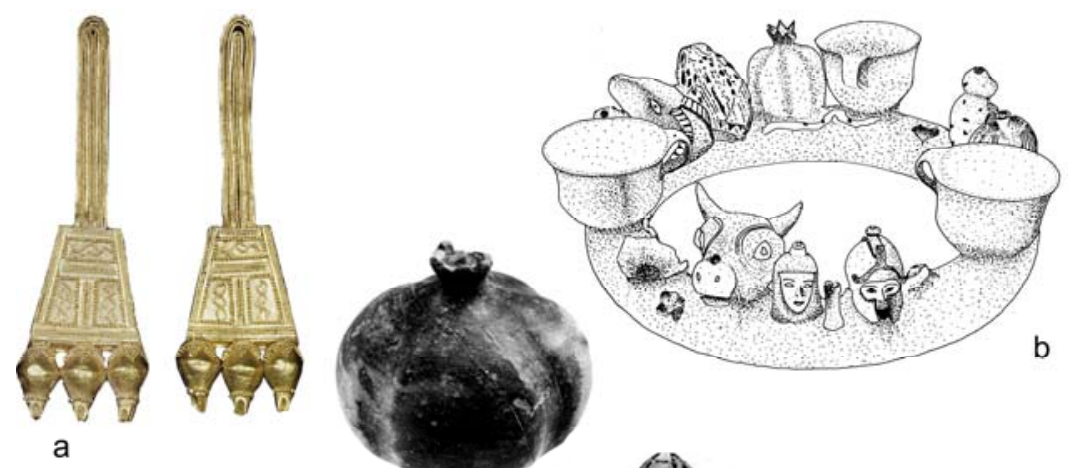

C
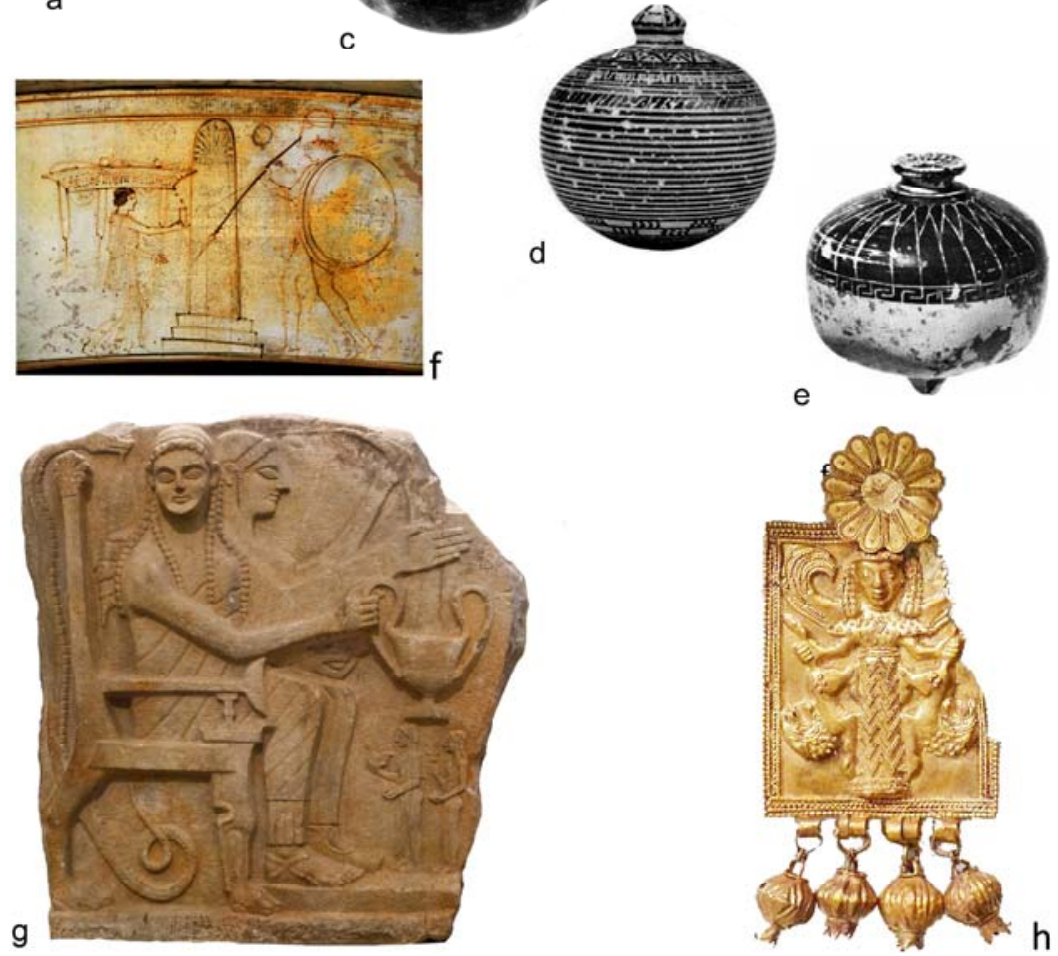

Fig. 9 - Greece: a - golden earrings from the tomb of the Rich Lady of Areiopagus, Athens, (mid- $8^{\text {th }}$ century BC); b - votive kernos from the Heraion of Samos (second half of $7^{\text {th }}$ century BC); c - pomegranate clay model from the Heraion of Samos; $d$ - pomegranate vase from Athens, Geometric Period; e - pomegranate vase from Rhodes (mid- $6^{\text {th }}$ century BC); - painted decoration of a White-ground Attic lekythos showing a young woman carrying ribbons and pomegranates (mid- $5^{\text {th }}$ century $\mathrm{BC}$ ); $\mathrm{g}$ - funerary relief from Chrysapha (Sparta), probably representing enthroned Hades and Persephone/Kore. The goddess holds a pomegranate in her right hand (550-540 BC); h - golden plaquette with the Potnia theron from Kamiros, Rhodes, 720-650 BC; Ashmolean Museum, Oxford. 

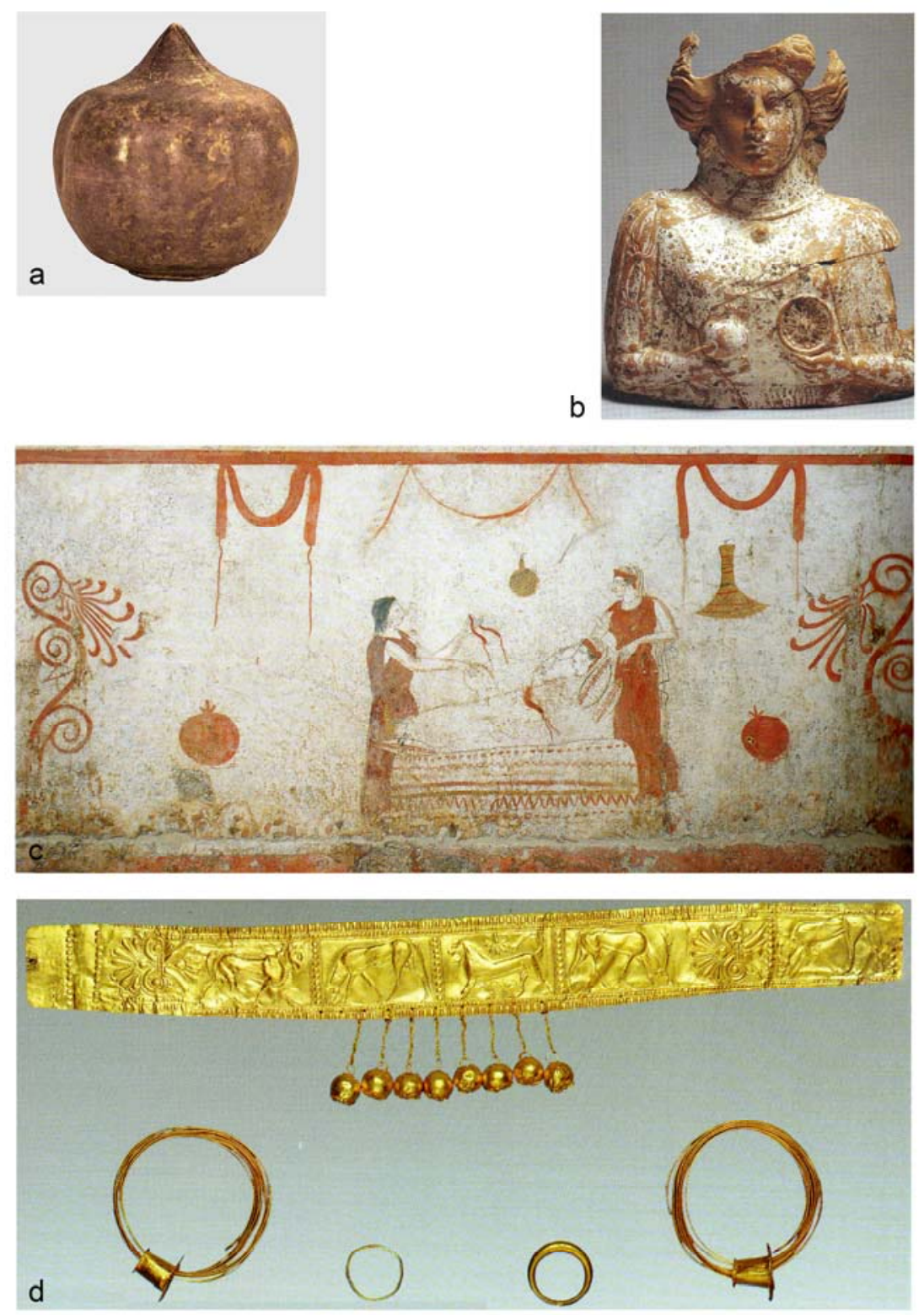

Fig. 10 - Southern Italy and Magna Graecia: a - clay model of pomegranate from Tempa Cagliozzo di San Martino d'Agri (PZ); b - clay statuette of Demeter from Ferrandina, Metaponto (MT), holding a patera and a pomegranate on her hands $\left(4^{\text {th }}\right.$ century BC); c Paestum (SA), Tomb 87 of Spina Gaudo (4 ${ }^{\text {th }}$ century BC); d - Braida del Vaglio (PZ), jewels from Tomb 102 (6 $6^{\text {th }}$ century BC). 
a
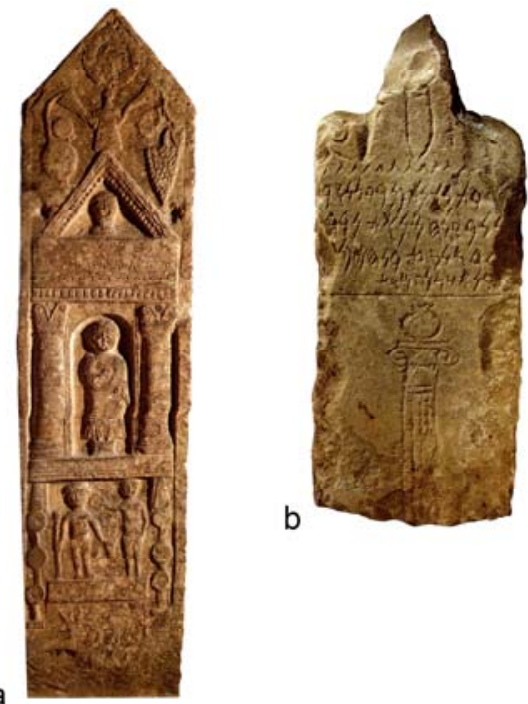

C
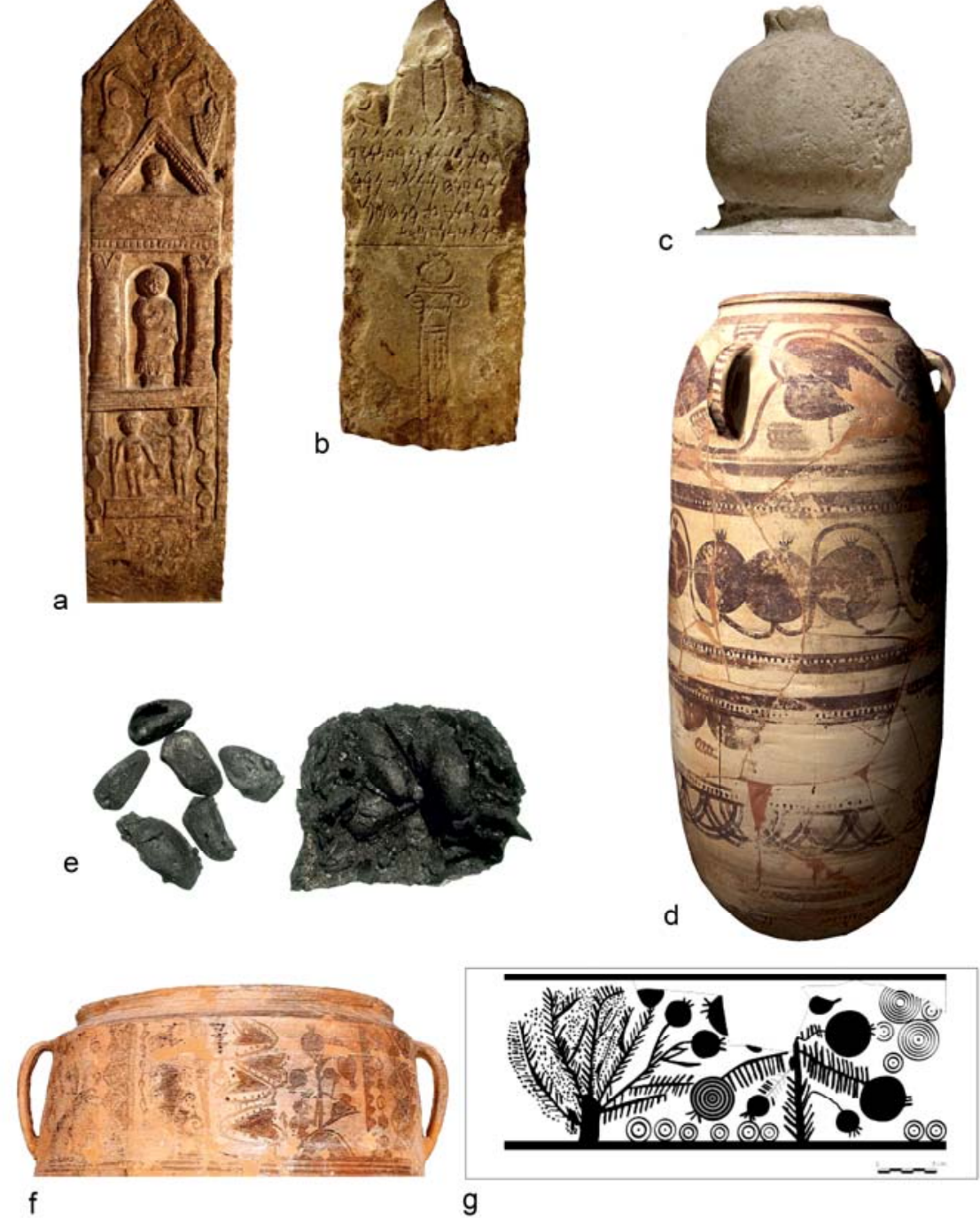

Fig. 11 - North Africa and Iberia: a - La Ghorfa (Maktar) funerary stelae ( $2^{\text {nd }}$ century BC); b - Carthage, stelae from the Tophet $\left(2^{\text {nd }}\right.$ century BC); c - Tútugi necropolis (Granada), stone cover knob in shape of pomegranate $\left(5^{\text {th }}\right.$ century BC); $\mathrm{d}$ - Coimbra de Barranco Ancho (Jumilla), Punic amphora painted in red with a pomegranate garland $\left(5^{\text {th }}\right.$ century BC); e - Puntal dels Llops (Olocau, Valencia), carbonized seeds of pomegranate found inside a Punic amphora (beginnings of $2^{\text {nd }}$ century BC); $\mathrm{f}$ - Edeta/Tossal de Sant Miquel de Lira (Valencia), painted jar no.6 dep. 5, particular of the upper decoration with pomegranate tree; $g$ - Puntal dels Llops (Olocau, Valencia), particular of the painted vegetal decoration with a pomegranate tree at the centre of the jar no. 4084 dep. 4. 


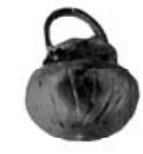

a
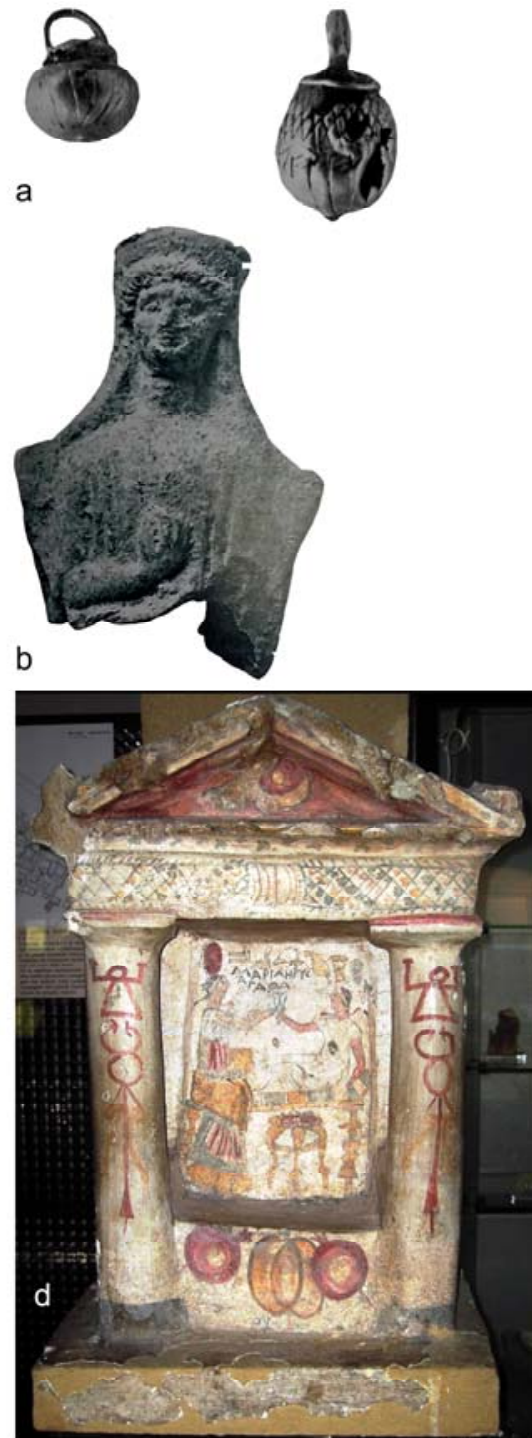

C
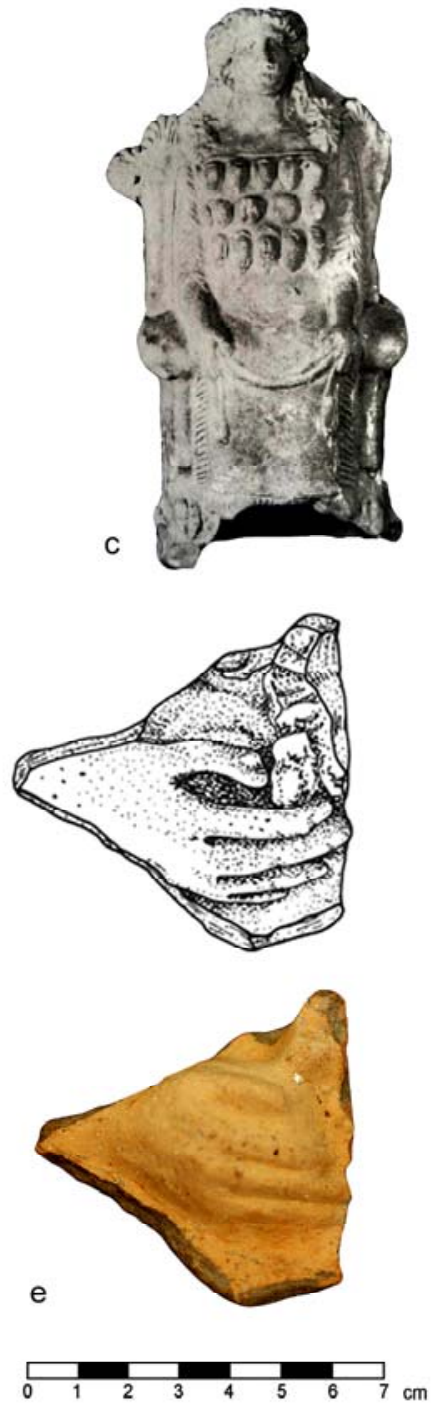

Fig. 12 - Sardinia and Sicily: a - golden pendants in the shape of pomegranates from Tharros, Collezione Chessa (D63 and D64) $\left(6^{\text {th }}-5^{\text {th }}\right.$ century BC); $b$ - terracotta enthroned goddess with polos, identified with Demeter from Tharros $\left(5^{\text {th }}-4^{\text {th }}\right.$ century BC); c Hellenistic terracotta representing Demeter seated in throne wearing a multiple necklace of shoots and pomegranates; $d$ - Lylibaeum (Marsala). Punic funerary stelae illustrating a scene of banquet and decorated on the basis with pomegranates and a quince; e - Motya (Sicily), fragment of a terracotta plaquette (MC.08.210) representing a female hand holding a pomegranate, found in the sacred Area of the Kothon $\left(5^{\text {th }}\right.$ century BC). 


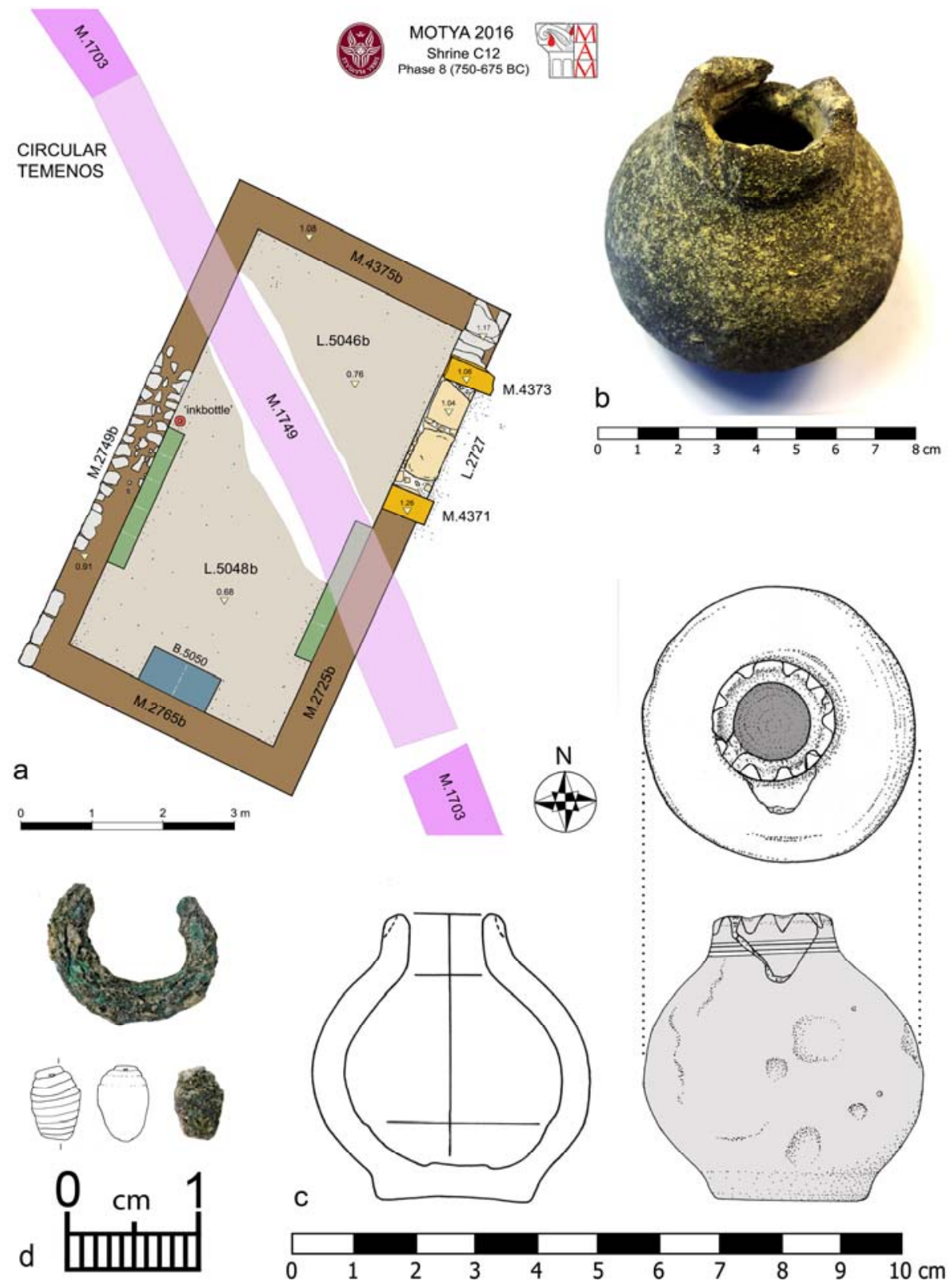

Fig. 13 - Motya: a - plan of the Temple of Astarte (Shrine C12) with indication of the finding spot of the pomegranate vase, Motya IVB, Phase 8, 750-675 BC; b-c - pomegranate vase MC.16.5046/1 found inside the Temple of Astarte at Motya (same dating); $d$ - bronze miniature earring and pinecone found in Shrine C12 possibly belonged to a cult figurine. 

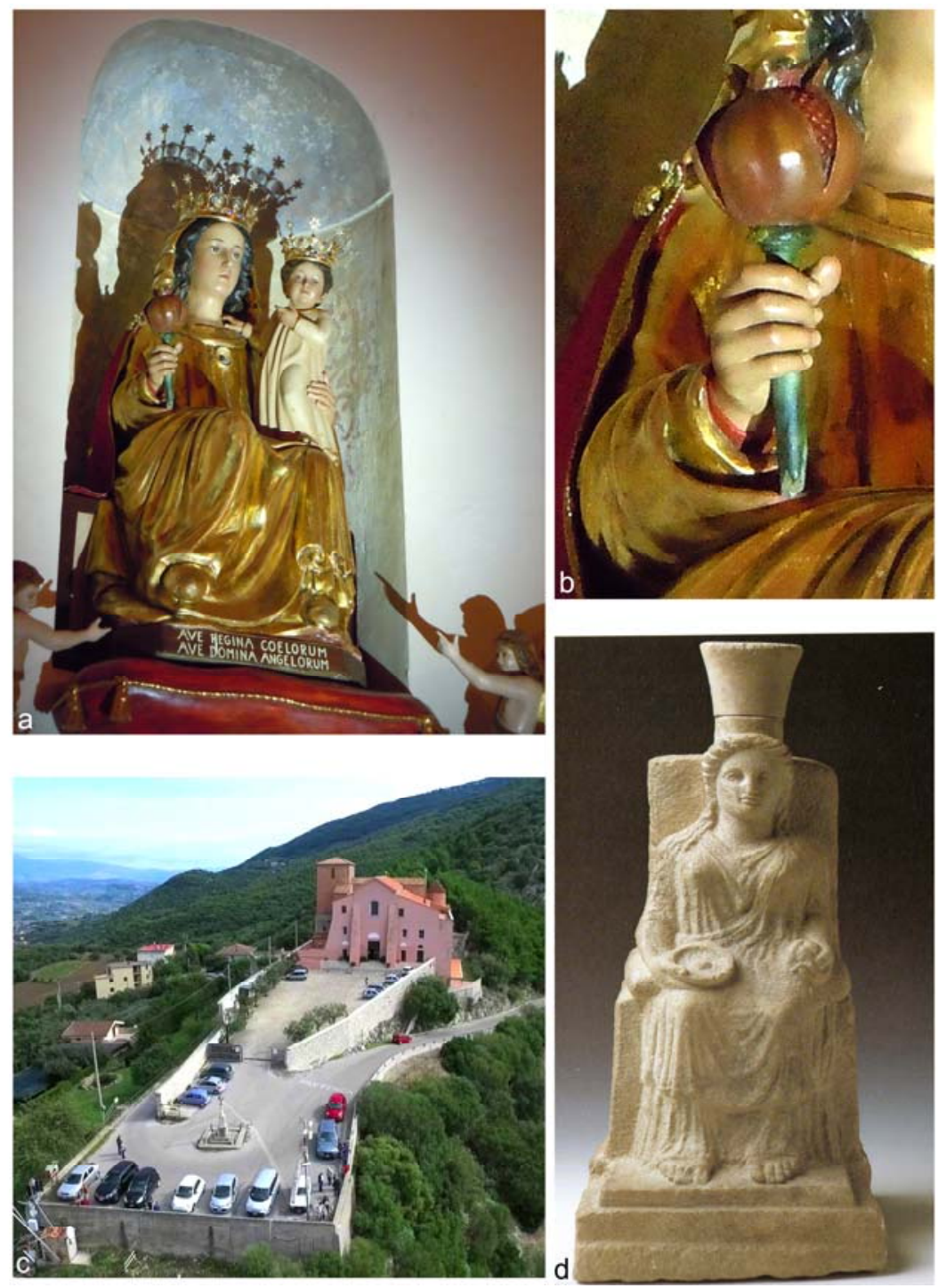

Fig. 14 - Capaccio (Paestum): a - statue of the "Madonna del Granato" in the homonym church at Capaccio Vecchio (Salerno, Italy), beginning of the $18^{\text {th }}$ century AD; $\mathrm{b}$ - detail of the sceptre with pomegranate finial in the right hand of the Holy Mary; c - aerial view of the Sanctuary of the "Madonna del Granato" built in the $10^{\text {th }}$ century AD as reminiscent of the former Temple of Hera in the underlying valley of river Sele, near Salerno/Paestum; $d$ seated limestone statue of the Goddess Hera holding a patera and a pomegranate from the Hearion by the mouth of river Sele, not far away from Capaccio in the Salerno/Paestum Plain. 

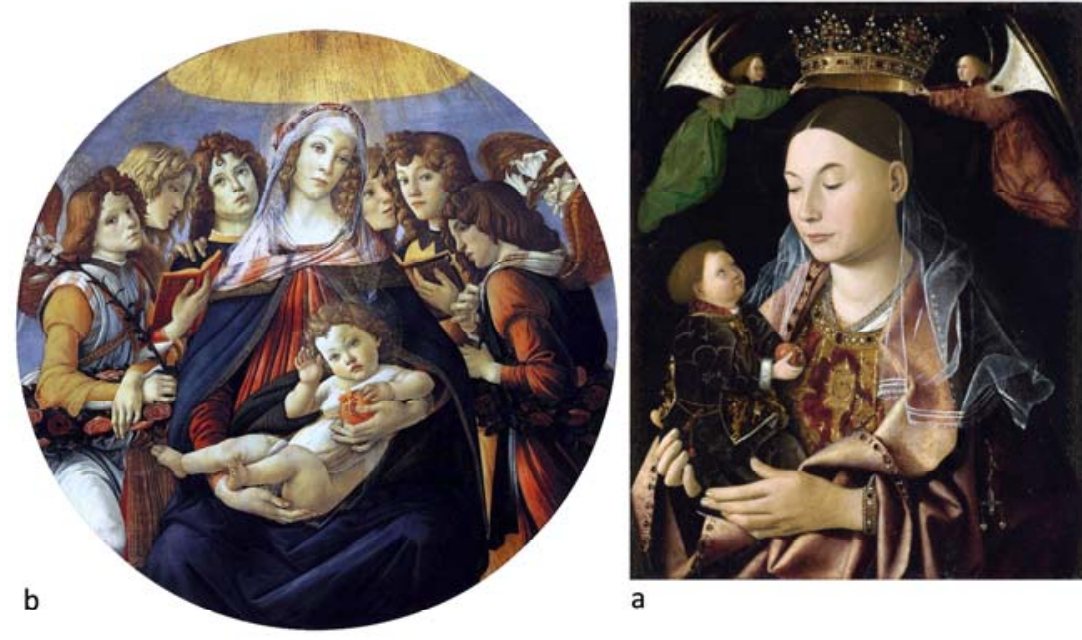

a
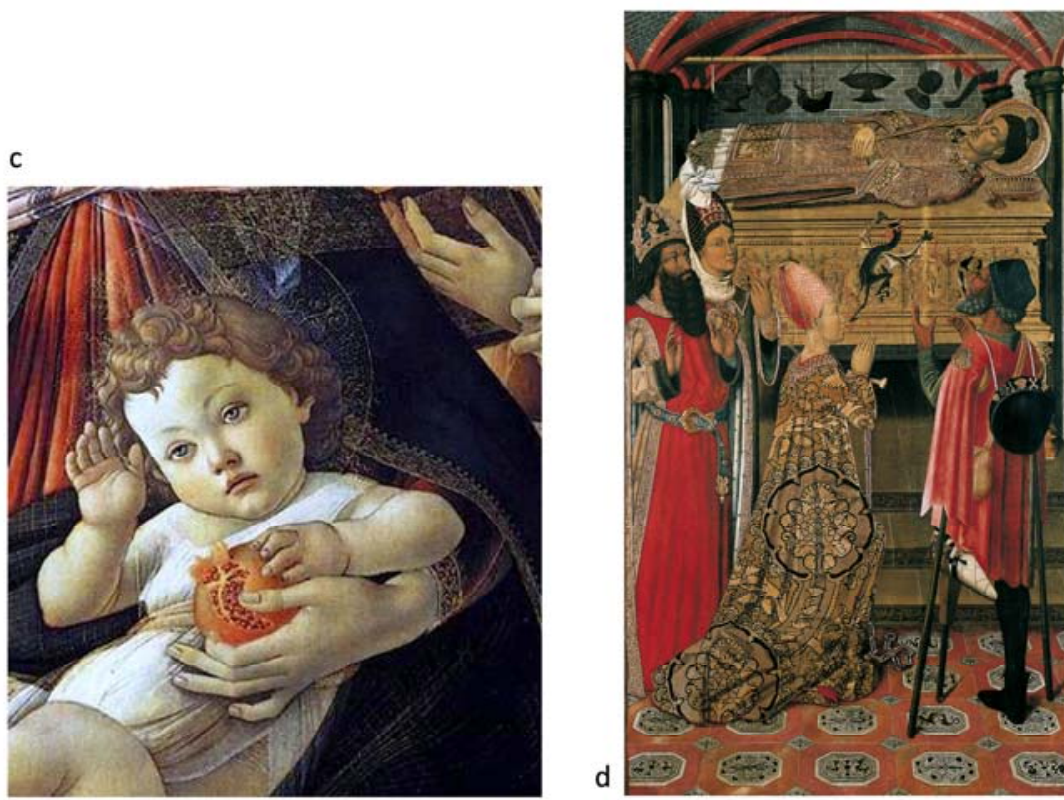

Fig. 15 - Renaissance paintings: a - Londra, National Gallery Antonello da Messina, "Madonna Salting", 1469, various techniques on wood; Firenze, Galleria degli Uffizi Sandro Botticelli, "La Madonna della melagrana", 1487, tempera on wood panel; b - detail of the infant baby Jesus holding a pomegranate; c - Barcelona, Museu Nacional d'Art de Catalunya, "The Exorcism of Princess Eudoxia before the tomb of Saint Stephen", Jaume Vergos II, 1495-1500, tempera, stucco reliefs and gold leaf on wood panel. 